In Conventions and Structures in Economics

Organization, Markets, Networks and Hierarchies, Edited

by Olivier Favereau and Emmanuel Lazega, Edward Elgar Publishing, 2002, 147-199.

\title{
6. Interdependent entrepreneurs and the social discipline of their cooperation: a research programme for structural economic sociology in a society of organizations
}

\section{Emmanuel Lazega, Lise Mounier ${ }^{1}$}

\author{
INTRODUCTION: BUREAUCRACY AND COLLEGIALITY AT \\ THE INTERORGANIZATIONAL LEVEL
}

Economists have long focused on markets as exchange mechanisms, and many economic sociologists have also used the same approach. This emphasized the importance of the price mechanism and the social embeddedness of economic transactions among actors, whether individuals or organizations. Focusing on the production side of economic activity underlines the fact that society is a society of organizations (Presthus, 1962; White, 1986; Stokman et al., 1985; Coleman, 1990; Perrow, 1991), with specific social mechanisms underlying collective action. But saying that society is an organizational society is also equivalent to saying that its intrinsically multi-level dimension should frame - much more than it currently does - sociologists' perspective on human, including economic, activity. In our view, this additional focus reframes analyses of both market exchange and social exchange (Blau, 1964) of resources as they are connected in production. This approach advocates new combinations of theories of individual action and theories of collective action. Within such a perspective, priority is given here to the study of social exchange and cooperation among interdependent entrepreneurs, at the intraorganizational and interorganizational levels. In short, this study is about the social discipline that helps interdependent entrepreneurs in their collective action. Entrepreneurs are not conceived as individuals acting on their own, but as individuals interacting with, and investing in, other entrepreneurs as peers or quasi-peers in order to make collective action possible.

The sociology of organizations has been able to design an ideal-typical 
distinction between two forms of collective action at least at the intraorganizational level. The two forms are bureaucracy and collegiality (Weber, 1978; Crozier, 1963; Lazega, 2001a). The first imposes an order in routine production; this order is built on formal hierarchy and rule circumvention by weaker parties. The second organizes non-routine work based on formal equality between interdependent entrepreneurs and identifiable social mechanisms of cooperation that can only be understood on the basis of structural analyses of multiplex social exchanges among economic actors.

For the last decades, structural analyses of social mechanisms taking place within and between organizations have contributed, more or less intentionally, to such a development in economic sociology. In this chapter, we sketch some of the main aspects and limitations of this early development. We then review new directions for research based on these expanded ambitions for current economic sociology. In particular, we ask whether it is possible to extend to the interorganizational level theory and models developed at the intraorganizational level to account for collective action among interdependent entrepreneurs (especially when production is not routinized and products are not standardized). A multi-level approach does not presuppose, for example, that the relationship between a boss and his worker is the same as a relationship between a large company and its subcontractor. Nor does it consider the distinction between market and hierarchy as a useful one for economic sociology. ${ }^{2}$ It is argued here that, although there is no scale invariance in the social sciences, the ideal-typical distinction between bureaucratic and collegial forms of collective action can be useful to understand coordination at the interorganizational level.

For example, at the interorganizational level, bureaucratic order is comparable to State planning ('external' regulation of the economic world, redistribution of resources providing forms of 'universal' solidarity and, sometimes, of generation of change). ${ }^{3}$ In recent history, the social systems in which this order was reified have not been able to muster the capacity to grow and innovate to an extent comparable to that of less bureaucratic systems. In the latter, exceptional growth is often exclusively attributed to the dynamics of the 'market economy'. In our view, it can also be attributed to the logic of politicized social exchange and to the derived generic social mechanisms that make it possible for an oligarchy of interdependent entrepreneurs to cooperate and get involved in collective action by acting at the interorganizational level. This level refers to the specific social phenomena that transform micro individual and relational behaviour into social mechanisms that structure the collective at the macro level. Generic social mechanisms - for example, that of generalized exchange (that is, bounded solidarity), control and regulation - were identified using a structural approach at the intraorganizational level, and concatenated under the label of the 'corporate social capital' (Lazega and Pattison, 2001). 
They combine entrepreneurial investments in relationships and the subsequent quest for social niches and status competition, two phenomena that come out of members' rationality in social exchange. These phenomena make the meso level a tangible and measurable reality. Our chapter asks how and to what extent such meso-specific mechanisms, that is mechanisms relying on the creation of social niches and more or less consistent forms of status, operate at the interorganizational level.

Differences between the intraorganizational and the interorganizational levels abound. At the macro level, more brutal and often more impersonal forms of status - impersonal concentrations of resources that stress raw power more than symbolic authority - are sought and used. The social niches that can be found at the interorganizational level combine resources that are different from social niches at the intraorganizational level. But similarities across levels are also striking. For example, the idea of an intraorganizational social niche is similar to that of a group of corporate actors depending on similar resources and providing each other with such resources at a lower price than would be expected with other exchange partners (Granovetter, 1994). Thus it makes sense to try to extend to the interorganizational level reasoning that was developed on interdependent entrepreneurs at the intraorganizational one, with adjustments concerning kinds of resources, niches and statuses that make sense at that higher level.

The existence of a meso level of analysis between the micro and the macro levels is a precondition of this theory connecting individual and collective economic behaviour. The current neostructural renewal of economic sociology rests on the development of multi-level methods of data analysis (particularly network analysis ${ }^{4}$ ) and on theories of action that do not accept a narrow conception of individual rationality. Any sociological theory of economic behaviour must rely on a realistic conception of the actors who produce and exchange. Early structural sociology used conceptions of actors that ranged between the automaton and the narrow cost-benefit maximizer. Here we build on an approach that seems more adequate for our purpose, one that brings in politicized social exchange to account for the social mechanisms characterizing cooperation in the organizational society more generally. In effect, our approach assumes that social mechanisms are triggered by relational choices made by actors. Such choices select exchange partners and this selection is understood as a niche-specific relational investment. Investments and their underlying commitment (to exchange partners) contribute in turn to the emergence of meso-level relational structures (regularities in the exchanges of resources), but also trigger the generic social mechanisms mentioned above. Without such mechanisms, we argue, collective action among interdependent entrepreneurs would not be possible at the micro and macro levels.

In effect, relational investments and commitments are made under specific 
conditions characterizing social exchange. They appear to be dyadic in nature (that is, to be 'gifts'), but they actually presuppose the existence of collectives in which dyads are embedded. Commitments have a multi-level dimension. They are made to actors (exchange partners) in social niches, using identity criteria. They happen when actors can define their situation using appropriateness judgments and identity criteria in the selection of exchange partners, from whom they expect, directly or indirectly, successfully or unsuccessfully, reciprocal investments and commitments (Lazega, 1992a). From the inside of the quasi-group, such commitments are perceived as homophyly; from the outside as density and embeddedness.

Contextualizing their economic activities in this way helps actors seek social niches and compete for status (with attached authority arguments and control of various kinds of resources). In effect, in our view, that would surely be consistent with that of many organizational sociologists (Crozier and Friedberg, 1977), these investments in exchange partners are part of actors' micropolitical behaviour. Actors tend to politicize their exchanges. They try as much as they can to shape and reshape their opportunity structure by influencing events at the meso level. This broadly conceived theory of rationality in social exchange includes an actor's capacity to contextualize his or her action. It brings in power and resource dependencies, but also social and cultural disciplines subsumed under regulatory activities (Reynaud, 1989; Favereau, 1989, 1999; Lazega, 1999a). In that respect, this neostructural approach combines rational choice ideas with more symbolic interactionist and strategic perspectives that will be outlined below - but also with formal and systematic modelling.

This chapter thus outlines the contribution and limitations of a broadly conceived structural approach to the study of organizations and markets. The specificity of structural studies is in their use of network analysis as a method for tracking and understanding flows and exchanges of resources, their control and rule enforcement, and finally the negotiation of rules commanding such flows and terms of exchanges. We mainly argue that the collegial model (developed to analyse social mechanisms of non routine cooperation between interdependent intrapreneurs at the intraorganizational level) can offer insights into, and hypotheses for, the study of interorganizational cooperation between interdependent entrepreneurs. Based on such an approach to economic activity, the strong difference between markets and organizations tends to be replaced by the dialectic interplay between mechanisms characterizing bureaucratic and collegial coordinations in each of the two contexts (intraorganizational and interorganizational). The boundary between the two forms of coordination, however, is a permanently shifting one. In effect, the forms taken by actors' social exchanges and politicized contextualization of their actions - and therefore their efforts to reshape their opportunity structure - 
depend heavily on the extent to which their tasks in collective action can be routinized, which is an unstable constraint. In our conclusion, we raise this issue of a possible typology of equilibrium points stabilizing the mix of collegiality and bureaucracy that can be found in any real-life organization and perhaps between them as well.

\section{EARLY STRUCTURAL APPROACHES TO ORGANIZATIONS AND MARKETS}

Network analysis in itself is a method, and its early users did not rely on many complex behavioural assumptions. They often used a conception of action that very generally looks at structural constraints imposed on the behaviour and opportunities of members of a social setting (White, 1970) and of reactions to such constraints (recorded as cutting and switching ties) that are eventually supposed to lead to a change in the structure. In early structural explanations in sociology, individuals were portrayed as being subject to particular sets of constraints and opportunities defined by their social context, such as specific and pre-existing social networks through which many resources can circulate (White et al., 1976). Although this micro-macro relationship has not been examined systematically, the approach has been productive for the study of organizations and for economic sociology. Of particular importance to understanding such constraints, social relations are part of the contextual conditions influencing behaviour, including economic calculations. Early structural approaches to organizations and markets use this method without, or with minimal, theory of action: narrow rational choice and resource dependence theory (Salancik and Pfeffer, 1977), the latter being primarily interested in the relationship between exchange, dependence and power. ${ }^{5}$

These constraints were theorized by the concepts of status and role without much reflection on the use of authority that status provides or on the enactment of such roles. In our view, this means that structural approaches should beware of explanations of actors' behavior and achievement simply by stating that they were 'at the right place, at the right time'. This is where a theory of politicized management of resource interdependencies and status competition is needed.

\section{Early Intraorganizational Network Studies}

For the last 30 years, organizations have been among the social settings most studied by network analysts: mines and shop-floors (Kapferer, 1969, 1972), monasteries (Sampson, 1969; Breiger et al., 1975; Reitz, 1988), banks (Eccles and Crane, 1988), advertising agencies (Ibarra, 1992), hospitals (Stevenson, 
1990), corporate law firms (Lazega, 1992b) and many others (Baker, 1984, 1992; Blau and Alba, 1982; Brass, 1984; Burt and Ronchi, 1990; Knoke and Wood, 1981; Krackhardt, 1990; Lemieux, 1979, 1982; Shrader et al., 1989; Thurman, 1980). Although some issues are dominant in this body of work (organizational integration; relationship between centrality, autonomy and power; influence of relationships on decision making; invisible inequalities), intraorganizational studies using network analysis deal with a wide variety of topics. For example, they describe the ways in which work, advice or friendship ties cut across internal formal boundaries such as departmental or status boundaries (Baker, 1992; Brass, 1984; Lazega, 1992b). They show how a system filters information that reaches its members (Rogers and AgarwalaRogers, 1976) and influences the flows and exchanges of various resources (Stevenson, 1990).

For example, a study by Burt (1992), following Harrison White and Mark Granovetter, stresses the importance, in a social structure, of absences of relationships between actors. A 'structural hole' is defined as an absence of ties between redundant others (that is contacts who give access to the same social resources). Burt uses the concept to develop a measurement of structural autonomy. An actor is autonomous when his or her contacts are not connected to each other - for many possible reasons - and cannot put together strong constraint on his or her behaviour. A simple example is that of two competing suppliers that a firm can play off against each other. With the idea of structural holes, Burt generalizes his theory of autonomy, adding that it provides benefits in information and control that every entrepreneur needs to seize opportunities. Absences of ties among others are exploitable by a tertius gaudens (in the Simmelian sense of a third party taking advantage of a blocked situation between two persons). With these premises, Burt develops a theory of this entrepreneur. An actor whose network is rich in structural holes will benefit from this structural feature when he can play them against each other or become an intermediary. On the basis of this advantage, a productive 'social capital', he or she will be in a better position to win in selection processes such as promotions. Actors paralysed in positions where they have to manage many heterogeneous relations simultaneously and where they have few opportunities to become unavoidable intermediaries, are destined for quick burnout. Burt thus pushes his structural theory of social capital towards a theory of inequality and selectivity of social systems. His work leads to a focus on actors' manipulation of relations (network surgery including cutting and adding ties from and to one's network) and cooptation as a defence mechanism (if you can't beat them, join them) where a strategic player tries to avoid competition or diminish his or her dependence upon a constraining party. These manœuvres can also be indirect (Gargiulo, 1993; Lazega and Vari, 1992; Lazega and Lebeaux, 1995; Lazega, 1995; Lazega and Krackhardt, 
2000). In Burt's early approaches, members' behaviour and management of ties are assumed to be driven exclusively by cost-benefit calculations.

\section{Early Interorganizational Networks Studies}

Many resources also flow among organizations, for example capital, personnel, information, goods (Aldrich and Marsden, 1988; Galaskiewicz and Marsden, 1978). In addition, as shown by studies such as that of Bauer and Cohen (1981) or Stokman et al. (1985), interorganizational relationships are also characterized by a great number of 'non economic' exchanges. Again the dominant literature on this field is that of resource dependence theory. These approaches differentiate themselves from atomistic approaches by defining the environment as a set of other organizations. For example, organizational systems can be centralized and hierarchical, as with a group with a dominant holding company at the top, or fragmented in a large number of small organizations, they can be disorganized as in the beginning of an industry or in a highly competitive system (Mintz and Schwartz, 1985); or display a limited number of coalitions as in the system of financial and marital alliances between houses in 15th century Florence (Padgett and Ansell, 1993).

Davis and Powell (1992) identify three different directions taken by research on interorganizational networks. The first two remain merely descriptive. The third develops a complete approach which has been influential in economic sociology.

The first direction is concerned with formation and maintenance of these networks. It uses mainly interlock ties (that is, ties between two companies created by the fact that one person sits on both boards). The reason for this interest in these ties goes back to problems raised at the beginning of the 20th century by cartels, collusion and antitrust action taken to be consistent with an ideology of open competition in capitalist economies (Mizruchi, 1982, 1992; Schwartz and Mizruchi, 1988). The second direction is represented by studies of the way position in the network of organizations, or organizational 'field' (DiMaggio, 1986), influences corporate actions, for example philanthropic giving (Galaskiewicz, 1979, 1989), top managers' political ideology (Useem, 1984), choice of a defence strategy against hostile takeover bids (Davis, 1991), and many others. In the same direction, Laumann and Knoke (1987) studied empirically the influence of interorganizational networks on lobbying and policy making in two ministries (health and energy) in the United States.

Finally, the third direction is concerned with evaluating profitability and chances of survival of companies given their position in the informal structure of their sector (Burt, 1983, 1992; Burt and Talmud, 1993). Market stability (Burt, 1988) and firm survival in a competitive arena are also among the main dependent variables. ${ }^{6}$ For example, Barley et al., (1992) try to explain strategic 
behaviour of companies in the new biotech industry, behaviour such as alliances and management of uncertainties arising from interdependencies with competitors. They show that one cannot explain these firms' behaviour without knowing their position in the structure created by all the organizations of the same sector. Analysing relationships between 900 organizations, as well as 700 contracts among them, they show that the firms may be clustered in blocks in which members tend to have the same alliance strategies and same level of participation in various segments of the market. Another example in the financial sector is Baker's $(1984,1990)$ empirical study of the informal structure of the Chicago options exchange. He has shown that price volatility of some products is higher at the periphery of the structure than at its centre, thus depending on the status of brokers.

This approach has generated fundamental ideas with regard to cooperation and competition in collective action. Pioneering work by Harrison White (1981a, 1981b, 1988, 2001) renews economic sociology by emphasizing the importance of the social structure of markets and the way in which social relations (as opposed to prices) regulate economic behaviour of competitors on specific markets, or the way in which the social structure influences pricing itself and other behaviour on competitive markets (Burt, 1992; Burt and Talmud, 1993; Leifer and White, 1988). White built an early sociological model of the market economy (recently extended, White, 2001) based on the existence of niches and blocks of producers watching each other's revenues, commitments to volume and choices of quality of products. As in Schumpeter's theory, producers do not focus first on demand, but on other producers. By definition, exchanges are never bilateral, always multilateral (and thus politicized). Instead of converging towards a single optimal price, they attempt to find a niche (defined as a combination of volume and the quality/price ratio) that allows them to create an ever-precarious market situation. Markets are thus organized from the perspective of niche-seeking producers and tend to segment into temporarily protected but fragile non-competitive economic niches.

It is interesting to notice here that several authors have used the concepts of niche to account for economic phenomena. In his seminal paper (1981b) and book (2001), White looks for conditions under which a market comes into existence and sustains itself. He considers a niche to be a market footing for a single firm and a single product, created mainly by consumers' quality judgment about (and ranking of) the product offered by this firm. This niche is thus socially constructed by producers watching each other, and by a 'typical consumer's' decision; notice that this construction is not a form of collective action because there is no joint and coordinated involvement of producers and consumers in the process. Obviously, this does not necessarily overlap with the definition of a social niche provided below as a set of exchange partners 
allowing easier access to multiple resources and developing common identifications and commitments. In the new version of his model, White (2001) 'turns the downstream model inside out' and models the behaviour of producers concerned with their upstream connections. But although, paradoxically, Harrison White is one of the pioneers of structural approaches to markets, his own model assumes the existence of an underlying social structure (connecting producers) without actually looking at the social and political mechanisms that maintains it (including professional associations, political parties, country clubs and non-profit organizations). Managers are concerned with the size of their production runs, not with joining or creating groups of organizations to concentrate their power or deal with their interdependencies. In White's view, a niche is not a segment of a market in which actors agree to a partial suspension of strategic behaviour and competition, in exchange for more control of each other's behaviour, be it informal. It is mainly a monopolistic position of the firm to be secured and derived from a characteristic of the product and to be obtained from the typical consumer's quality orderings. Thanks to network analytical partition methods, one finds here familiar segmentation processes such as that characterizing labour markets (Granovetter, 1985, 1992; Swedberg, 1990, 1992). ${ }^{7}$

Other work in this third direction (Berkowitz et al., 1979; Berkowitz, 1988; Berkowitz and Fitzgerald, 1995; as well as Mokken and Stokman, 1978), uses capital ownership ties combined with control interlock ties to define entities called enterprises. A company in a context of multinational groups operating at the global level is not a unit of analysis that must attract interest first in order to define a market. Berkowitz defines market areas as clusters of companies producing, distributing and consuming various goods in an upstream-downstream flow. This new overlay offers a picture of competitive markets at various levels of complexity. These models are more realistic than definitions of markets in technological terms in that they bring out institutional structures that protect market areas. Network analysis helps identify classical forms of market relationships (such as monopolies, duopolies, oligopolies or monopsonies) as well as unnamed but simple and constraining socioeconomic structures.

This work often goes beyond simple monograph of informal structures of organizations or of interorganizational systems to test embeddedness hypotheses on the articulation of structure, access to resources and behaviour. They build sociological theories reinterpreting economic activity through a detailed and ethnographic knowledge of the business world and its relationships with the institutional, local and national, context. Such theories are not yet complete and able to explain collective action coordinated by mechanisms other than competition. However, their capacity to explain many economic phenomena reformats the debate between sociology and economy in the grand tradition of 
Weber and Polanyi, who conceive of markets as social institutions facilitating exchanges, that is, more than a pricing mechanism. It shows that it is useless to imagine interorganizational structures of cooperation that do not rely on multiple social resources and formal organizations, for example interorganizational 'structures' that would be made exclusively of contracts. By isolating the network of contracts from a formalized and organized social exchange, one kills its specificity.

Most of this early work was often based exclusively on narrow resource dependence theories taking into account social embeddedness. As shown by Lindenberg (1996), few behavioural assumptions, other than the prevalence of short term cost-benefit theories mitigated by social ties, are used to explain members' behaviour. It is, however, insufficient to explain how actors generate structures that encourage cooperation (as opposed to competition), or how to account for high levels of social exclusion provoked by contemporary market economies (Perrow, 1992). Therefore the next generation of structural sociologists has been trying to enrich the definition of the actor that is used to account for economic action. Specifically, since actors get involved in, and manage, exchanges of multiple resources, this calls for a theory of social exchange and barter.

\section{RATIONALITY, SOCIAL EXCHANGE AND STRUCTURE: THE IMPORTANCE OF THE MESO LEVEL}

Beyond utilitarian and embeddedness studies, a broader structural approach adds behavioural assumptions and multiplexity to a sociological theory of economic action. It assumes a form of actors' rationality that is compatible with social exchange, not only with market exchange. Social exchange includes calculations, but also symbolic activity ${ }^{8}$ such as appropriateness judgments, commitments and relational investments (based on boundary management and identity claims) and value judgments (negotiation of precarious values and norms) that allow individuals to contextualize and politicize their calculations and exchanges, at least by selecting reference groups, priorities in allegiances and authorities (Lazega, 1992a, 1997; Favereau, 1998, 1999). In our view, it is useful to assume that actors invest in relationships in order to act at the meso level, to try to reshape their opportunity structure, that is, to try to structure the context of their interactions They can do so, for example, in the process of selecting exchange partners. These selections are neither random, nor entirely free, nor entirely determined. As seen in the previous section, they are themselves subject to previous structural and normative constraints. But they nevertheless reflect the idea that actors invest in relationships in order to make some direct or indirect reciprocity possible. Actors 
often assume that they will benefit from this reciprocity in social niches, that is, if others share the same identities and rules of exclusivity. Rationality from a broadly conceived structural approach is inseparable from the processes characterizing social exchange.

One example that illustrates this approach to social exchange is the importance of barter. In economics, barter is a slow, expensive and highly restrictive way to do business. The barter economy is inefficient compared to the cash economy. Barter transactions are opaque and approximate. At the macro level, barter undermines good government because it makes tax collection difficult, tax evasion easier (for example, the tax man has to work harder, with much less precise information to understand a company's business). A country cannot prosper unless barter is replaced by conventional money. For economists, people barter, for example, when inflation is too high or because they make goods that are unsalable at any price and barter then becomes a way for them to restore price flexibility. There is barter entrenchment. It also becomes easier for people in power to manage barter to their advantage. However, in social life, barter is much more widespread than is usually acknowledged. It is used much more often than cash for many types of exchanges. And it has its own rules. It is indeed much more restrictive and it falls under a logic of membership, a symbolic logic; it is much more demanding in terms of solidarity with 'one's own people'. Basically, it identifies criteria that drive the barter economy, that is, a principle that is the exact opposite of the perfect market mechanism, in which people tend to be anonymous and unrelated. The barter economy is much more visibly politicized than the cash economy. And it is much more pervasive in the economy than conventional economists acknowledge. In effect, pricing many goods or resources is next to impossible for actors involved in transactions connected to production and collective action. This is especially the case for knowledge.

In addition, investments in relationships are not independent of status comparisons. In effect, actors need to define terms of social exchange, and status is an enviable position from which to negotiate such terms. The dynamics of status auctions in brainstorming is a good illustration: it is a multiplex process relying on several forms of status (Lazega and Pattison, 2001). There is, however, a permanent risk of opportunism attached to such relational investments. They therefore presuppose a definition of - and possibly a resort to - authorities. A social niche cannot operate on its own, without such external authorities. The latter are central in the processes of the definition of the situation, but also for the meso-level social mechanisms such as exchange or regulatory deliberation.

In our approach, we use the concept of rationality in a wide sense. Rational action means that one has a goal (or a series of competing or successive goals) and a series of means to reach these goals. For example, niche seeking is not 
an exclusive goal in itself but a strategy to reach a series of higher order goals. Niche seeking is sometimes based on a series of intuitive relation-specific investments guided by homophyly. Therefore it belongs to a form of rationality that is not exclusively concerned with cost-benefit calculation. The fact that it is not always experienced as rational in a narrow sense does not mean that it is not rational in a broader sense. The criterion of what is rational is not necessarily what is experienced as such on the spot. Therefore attributing such a form of rationality to interdependent entrepreneurs cannot be considered to be a form of 'scholastic fallacy' denounced by Bourdieu with regard to narrow rational choice theories. On the contrary, this form of rationality can be shown to be highly correlated to position in the structure (Lazega and van Duijn, 1997).

In the next section, we provide an overview of the contribution of strategic analysis and symbolic interaction as underlying sets of assumptions concerning actor's behaviour when involved in social exchange. We then look at their implications for economic activity at the individual level. Finally, we raise the issue of extending such a view of actors' behaviour at the interorganizational level.

\section{Resource Interdependencies and Investments in Relationships}

Actors depending on each other for resources are rational when they look for social niches, that is, contexts where their investments in relationships (with such selected partners) have a better chance of ensuring reciprocity both at the dyadic level and via generalized exchange (indirect reciprocity), and make social exchange, or barter, possible. They are trying to shape as much as possible their opportunity structure. This of course depends on their acceptance by others in the niche, so decisions to invest are not decisions that they can make exclusively on their own. These investments are the basis of generic social mechanisms that are multiplex and multi-level: multi-level because niches create a micro-meso and meso-macro articulation; and sometimes multiplex because some of these investments are exchanges of various kinds of resources needed for collective action (for example, both arm's-length and 'embedded' ties, as described by Lazega and Pattison, 1999, or Uzzi, 1999. Once investments in relationships have been made and once niches provide such positive returns, it can even make sense to risk (apparently sacrifice) some of these relationships themselves for the common good (see the case of lateral control regimes below) and for legitimacy needed to change the rules or maintain the status quo.

In other words, relation-specific investments are triggers for social mechanisms of cooperation. Before developing this proposition, it is useful to acknowledge two bodies of work that are particularly useful to this structural 
theory of social exchange focusing on investments in relationships and attempts to reshape opportunity structures. The first is an approach of power in terms of resource interdependencies, the second is an approach to commitment and identity. As we define it, social exchange requires both politicization of these exchanges, or barters, and coorientation with exchange partners.

\section{Trying to Reshape Opportunity Structures: the Contribution of Strategic Analysis}

An organizational approach to social life means, among other requirements, that individuals must be seen as interdependent members who need to get access to production-related resources (Crozier and Friedberg, 1977). At the level of organizations as units, resource dependencies are even more obvious. Because they rely on theories of power and resource dependencies, structural analyses are close to theories of collective action such as the French school of organizational analysis. Following the sociotechnical tradition of the 1950s, these interdependencies can be functional, that is related to a formal division of work, or structural, that is related to more informal circulation of all sorts of resources through social relationships. In that respect, structural analysis is compatible with what Crozier (1963; Crozier and Friedberg, 1977) calls 'strategic' analysis. Indeed, the former presupposes the latter. ${ }^{9}$ This is particularly the case because structural analysis offers sophisticated measurements of resource interdependencies, status and power that are basic concepts of both approaches. The latter rely on inductive approaches avoiding reification of the notion of structure.

In effect, to the notion of formal structure, strategic analyses (Crozier, 1963; Crozier and Friedberg, 1977; Sainsaulieu, 1987) add the notion of a concrete action system. This system is partly defined by the relationships that are established among interdependent members in the organization or between organizations. Part of the task of strategic analyses involves bringing out patterns of informal relationships on which unexpected forms of order depend. In the structural perspective too, actors contribute to the raising of structures that end up constraining them. Formal and informal structures are now defined in the same terms, those of resource dependencies. Notions such as power and autonomy are measured in various types of centrality and constraint scores that take into account the relational and systemic dimensions of these phenomena. Structural advantage and disadvantage are made more visible.

Beyond these general similarities, structural and strategic analyses also meet in the study of two fundamental dimensions of power games: first, actors' capacity to manage relationships, invest in them and disinvest; second, in the ways in which they politicize their exchanges. Sainsaulieu $(1977,1987)$ has long insisted on the type of trained capacities that members develop in 
order to 'become actors' - whether cognitive capacities (identifying key players and relationships among them) or manipulative capacities (creating coalitions, letting relations dissolve or cutting ties). Such an approach is very close to that of Krackhardt (1987, 1990, 1992; Krackhardt and Hanson, 1993) and his exploration of the relationship between power and perception of relations; or to that of Kapferer $(1969,1972)$, Burt (1992) and other network analysts interested in direct or indirect cooptation and influence (Brass, 1984; Gargiulo, 1993; Lazega and Vari, 1992; Lazega and Lebeaux, 1995; Lazega, 2000b; Lazega and Krackhardt, 2000). As a moment (analytically speaking) of politicized exchanges, the logic of regulatory work and deliberations has also been closely tracked by Reynaud (1989).

\section{Trying to Reshape Opportunity Structures: the Contribution of Symbolic Interactionism}

The contribution of symbolic interactionist theory to our assumptions concerning social and economic behaviour is less straightforward. The easiest way to theorize this connection is to use the notion of commitment underlying selection of exchange partners. Commitment to others, but also to shared identities, is an old symbolic interactionist topic. From this perspective, social order is constructed through meaningful, self-other interaction (Blumer, 1969) under the 'surveillance' of reference groups, an audience which is not necessarily empirically present, but nevertheless exercising social control, and thus constraining behaviour by judging of its appropriateness and legitimacy. In this context, the question of the structure is raised in terms of institutional constraints influencing negotiations of identities that, in turn, weigh on appropriateness judgments (McCall and Simmons, 1966; Lazega, 1992a). Since most interactions take place in situations that are never completely structured, nor necessarily clearly defined in actors' minds, actors may not necessarily know which of their identities will be involved, as a priority, in the current interaction, and which behaviour is more appropriate given the commitment to such identity. A phase of mutual identification, of identity negotiation and hierarchization, is necessary for interactions to take place. Joint identification with the image and attributes of a profession is all the more common in the business world in that people have to 'sell themselves' in order to hold their own. The link between the structure of the social setting and the interactive processes which take place within them is theorized through analyses of this negotiation.

Social exchange necessary for production cannot be theorized without the notions of commitment, identity and appropriateness judgment. In collective action, formal and informal identities are combined. A context can be modelled as a set of formal identities bestowed upon some members, with 
their attached power and authority. The informal set of identities is not necessarily recognized institutionally and thus rarely associated with authority. Actors' method of contextualization of behaviour is thus close to a symbolic interactionist conception of rationality. Certainly, networks are not providing actors with 'pure' and 'essential' identities but with a sense of the appropriateness in using formal attributes here and now when orienting or coorienting behaviour. Identity is not a benefit that actors extract from belonging to a network. It is a structural green light both for construction of ties (access to resources) and for coorientation of actions within a specific context (formal and informal structure) for one's rules. This approach goes beyond embeddedness studies that do not often explain how actors use and develop social ties for their exchanges and cooperation.

Another angle from which to grasp the conceptual proximity between structural and symbolic interactionist theories comes from analysing 'crystallized' ways in which economic actors participate in social exchange. This crystallization can be grasped through the notion of role as used in both perspectives. As seen above, the conceptual link between structure and behaviour in network analysis is often provided by the notion of role, which can be understood as the function performed from a position (for example a subset of approximately structurally equivalent members), or as a specified combination of relations compounding two or more different networks. Such operationalizations of the concept of role, like any model, simplifies the description of constraints on behaviour, especially because they are exclusively relational. For critics (Brint, 1992; DiMaggio, 1991, 1992), the role of cultural (in the sense of normative) orientations may be as important in the explanation of actors' behaviour, especially when structural constraints are multiple and sometimes contradictory. For most general theories of action, such as that of Nadel (1957), a role results from normative expectations and from relations with associates carrying these expectations and sanctioning deviance. This is true even if it may be difficult to find a relational basis for all rights and duties, for instance by identifying authority figures that represent them or speak on their behalf. Therefore roles are useful as a synthesis of individual and social levels, but also of normative and relational dimensions.

Accepting that economic actors try to reshape their opportunity structure by entering social exchanges as role performance does not mean subscribing to a rigid conception of roles. Blumer (1969) sees roles as sets of informal rules created and recreated through interactions, especially through negotiations between individuals and their associates. Actors and their interactions construct the roles and rules that govern their behaviour. Individuals participate in defining their own roles, which have many variations, and they usually undergo change (Stryker, 1980; Stryker and Statham, 1985). In that sense, two largely descriptive steps are involved in the analysis of roles. One is the 
description of the extent to which the informal definition of the role (role making) is closely related to the formal definition (role taking). The second is the description of the extent to which this redefinition is itself subject to relational constraints. These negotiations recreate and reshape roles, often with dogmatic emphasis on (always temporary forms of) conformity and consensus among stakeholders. Individuals' role-related behaviour is determined by expectations of their associates, and such expectations are themselves culturally coded. In order to link the institution and the individual, the structural approach defines roles as sets of norms that are widely endorsed by actors in their interactions, even if associates may change. At a very general level of abstraction, this symbolic interactionist approach to social exchange is also compatible with a conventionalist theory of economic activity. Indeed, rules subsume relational and cultural devices that are needed to make economic decisions, both calculating and interpretive.

In sum, individuals trying to reshape their opportunity structure can be represented as strategic but interdependent entrepreneurs who seek contexts in which they can find and exchange these resources at low cost. Once in such contexts, they seek various forms of concentration of these resources so as to be in a position to define the terms of such exchanges. This means that two notions are important to a structural approach of organizations: social niches and multidimensionality of status. Both are indispensable for members' durable commitment to a labour contract. They are basic components, not only of production, but also of a series of relatively general mechanisms that together characterize coordination of collective action from a structural perspective.

But a structural approach is more than just a refinement of strategic analysis and symbolic interaction. Access to production-related resources by interdependent members, as well as participation in power plays, are particularly visible in niche seeking and status competition. The latter activities are both consequences of actors' attempts to reshape their opportunity structures and the building blocks of the social mechanisms that help them achieve cooperation even with their competitors.

\section{Interdependent Entrepreneurs Seeking Bounded Solidarity in Social Niches}

Interdependent members of organizations must have access to various production-related resources (for example clients, co-workers' goodwill, advice). The social niche of an actor can be broadly defined as a subset of members of the organization with whom the actor has succeeded in creating especially durable exchange relations, whether directly or indirectly, as a consequence of his or her previous (and mutual, although not necessarily symmetric) investments. It 
is a pool of partners with whom exchanges are characterized by a certain density, which implies that sociologists can detect a niche through a strong relational cohesion, if not a generalized exchange system (Lazega and Pattison, 1999). ${ }^{10}$ Actors contextualizing their behaviour also detect the existence of niches, but they often use the criterion of a certain social homogeneity to do so: they use similarities (for example in terms of office membership, or speciality, or hierarchical status) between exchange partners to identify the boundaries of the niche in which they assume that dense exchanges do or will take place (Lazega and van Duijn, 1997). ${ }^{11}$ Ideally, such niches operate as pumps mixing and spreading various types of resources to members.

Members operate within micro structures such as niches, that are themselves part of a system of niches in the wider organization. Indeed, niches only make sense in a system of niches. It is rational for members to be niche-seeking because it is rational for them to look for multifunctional contexts that provide them with resources needed to produce, and with relative protection from rivalry and competition for these resources. ${ }^{12}$ The multifunctional character of niches means that several resources can be exchanged by members. Indeed, such niches are also built for that very purpose, that is, to allow multiplex barters of resources without 'general equivalent'. Niche building is strategic, but, once built, niches have the advantage of allowing partial suspension of purely calculating behaviour (Ekeh, 1976). They help members, as economic actors, identify partners with similar long-term interests and combine, through identity criteria, these long term interests and management of multiple resources. Niches and identities come together because they introduce long term stability in members' choices and definitions of interests. ${ }^{13}$ This stability is based on the intuition that common characteristics make long term common interests more likely, and therefore the existence of indirect reciprocity that is necessary to collective action. As seen above, there is no barter without identities and a very important symbolic dimension. Therefore they can be characterized by a form of bounded solidarity. This bounded solidarity is connected to a form of contextualization of action (Lazega, 1997) and limited rationality, in the sense that members do not always use the same criteria to evaluate the fairness of their multiplex barters. It can be measured in several ways: for example, by the stability of members' choices of exchange partners; or by boundary management (Lazega, 1992a) allowing for the existence of generalized exchange cycles, that is, of indirect reciprocity, among such partners; or by the presence of informal rules imposing multiplexity or marginalizing, then excluding, members who grab all the credit for successful actions.

To get access to such resources, members do not rely entirely on formal organization and rules. They are selective in their relational choices, and this selectivity, together with institutional constraints, produces patterns which are 
interesting for understanding exchanges in the firm. Members manage their interdependence in their own ways, that are both economic and political (Crozier and Friedberg, 1977). As seen above, to get access to such resources, they enter exchanges that are multilateral and multiplex. ${ }^{14}$ The contextual rationality that is at work in such exchanges plays with attributes and ties. ${ }^{15}$ It intervenes in the process of resource allocation by using formal attributes in 'politicized' ways or by introducing other particularistic attributes and preoccupations (for example gender, or law school attended). The latter are more informal and ad hoc; they are not necessarily officially recognized by the firm as characteristics that should be used to promote cooperation and allocate resources. The main concept to understand this stability and this process is that of identification. As mentioned above, identity is usually a relatively stable and multidimensional set of attributes that members use to make judgments of appropriateness, define themselves and get recognition as sources of their actions (for credit and accountability) on a continuing basis. In practice, an actor is always 'loyal' to some allegiance (represented by an attribute) while 'betraying' another (represented by another attribute). Identity is what introduces time in action by defining long-term individual and collective interests. Identities enter the exchange as bearings or markers or criteria for selection of exchange partners. Members use identity criteria to choose exchange partners who will presumably share values leading to some sort of solidarity. The idea here is that identity is introduced in transfers and exchanges of resources to avoid measuring the value of the heterogeneous resources in multiplex exchanges. The use of identities in multiplex exchanges creates a form of bounded solidarity.

In sum, a social niche offers its members resources, a sense of identity and of common long-term interests, a context for the enforcement of their own rules, and the stimulation that is needed to produce in common. Its generalized exchange system sustains cohesive and durable work relationships in contexts often dominated by flexibility and short-term calculations. It constitutes a bounded solidarity bloc. But recall that it can also become a difficult and very constraining environment, especially when members lose control of the status competition process.

\section{Interdependent Entrepreneurs Competing for Multiple Forms of Status}

Together with seeking or building niches as appropriate and protected contexts for part of their exchanges, members try to reshape their opportunity structure by attempting to manage the exchanges that take place in them. In this context of bounded solidarity, one way of influencing exchanges with colleagues is to accumulate resources needed for production, thus reaching a form of status. The role of status in the mechanisms supporting collegial organizations is 
complex. In general sociological theory, status refers to a member's relative position in the group, both in the formal hierarchy and in the networks of exchanges in the group. In collegial organizations, status comes from contributions to the firm, from credentials, from a history of achievements and establishment of competence. It means that the individual is considered worthy of being granted an extensive mandate, regarding both personal responsibility and corporate responsibility to regulate community, professional or internal firm affairs (Bosk, 1979). This mandate is derived from and made measurable by - concentration of production-related resources, or by the privileges that are granted to members who control such resources. These privileges may include financial compensation, decision-making priorities, more respectful treatment by peers, symbolic and moral licensing, as well as escaping pressure for accountability, tests of commitment, and blame for many errors. In addition to being less vulnerable to criticism from colleagues, and being insulated from cross-pressures, members with status have functional prerogatives including more freedom to select interesting matters and cases on which to work, thus authoritatively deciding how such cases will be handled and dividing the work among others.

It is not surprising, therefore, that members of a group compete for status, ${ }^{16}$ even if the latter comes with responsibilities, for example that of exercising a form of leadership, of being responsible for the long-term future of the organization. Other members expect from them solutions to their collective action problems and these convergent and constraining expectations play an important role in the structuration of cooperation. Elites are challenged to solve problems by alternating constraint and persuasion, to combine diverging interests of fractions hanging on to their rents within often confused and unstable coalitions. They are supposed to help maintain solidarity within the organization at large. But this leadership cannot be exercised without a concentration of social resources. This is where a relational and structural definition of power becomes important to understand status (Crozier and Friedberg, 1977). In effect, it is often the concentration of social resources that allows members to reach a form of status. And once in a leadership position, members need these resources to perform, to use others' dependencies and define terms of exchanges.

From a structural perspective, the concept of status is a composite of titles (official function) and accumulation of different types of social resources. This composite character is translated by the existence of multiple forms of status that can be used by actors to politicize their exchanges. Sociological classics have long stressed the importance and many dimensions of social status and social approval. Max Weber used to distinguish dimensions that were economic (based on revenue), social (honour, prestige, not only from birth, but from human capital - education) and political. For him, collective action is 
possible only because status has heterogeneous sources. As stressed by Parsons, then by Bourricaud, the functions of leadership are always exercised by several persons. The role of the leader is 'diffuse', not specialized. This multidimensionality of status is derived from the concentration of different resources, from an endogenous heterogeneity (and not only an exogenous one, as in Weber) of sources. For example, the official member, the most competent, the most popular, the most committed, all have some sort of status, and participate in coordination of collective action.

The question may be raised of the relationships between these different forms of status, if not their coexistence. Given that it is multidimensional, each of its forms may or may not go hand-in-hand with another form, often capitalized by someone else. For the individual, heterogeneity of sources of status may correspond to various levels of status consistency. In fact, it is the possibility of playing, at the individual level, with this status inconsistency that gives oligarchic systems the capacity to maintain themselves in equilibrium and to define a hierarchy of values (for more on this, see about this point the end of this chapter). In collegial systems, for example, multidimensionality of status comes usually with processes that help the organization maintain a balance of powers between oligarchs. Heterogeneity of sources of status often mean that an oligarchy reaches a form of equilibrium or stability based on the interdependency of oligarchs. Cohesion in the oligarchy is reached by a balance of powers and integration à la Montesquieu (Lazega, 1992b, 2000a; Kuty, 1998). Maintaining heterogeneity and interdependence of forms of status is often the condition under which rivalry among oligarchs leads to equilibrium.

\section{Investments in Relationships and Social Mechanisms}

The fact that actors are niche-seeking entrepreneurs, status competitors and judges of the appropriateness of their own (as well as others') social exchanges is important to understanding sociologically economic activity. Reaching and enforcing economic decisions are processes that depend heavily on the existence of social niches, of multi-dimensionality of status and of normative coorientation. The contribution of a broadly conceived structural approach to a theory of economic activity needs to take them into account. This is done by acknowledging that, when investing in relationships and trying to reshape their opportunity structure, actors trigger social mechanisms that can be vicious or virtuous.

In other words, relation-specific investments are triggers for social mechanisms. This raises a chicken-and-egg issue. We do assume that actors always act in situations that are already structured, but we do not assume that these structures entirely determine behaviour. For example Uzzi's (1999) work 
shows that organizational change may sometimes come from importing into the organization (banks) types of ties (social relationships with clients) that are built outside the organization. Signals providing a structural green light for specific kinds of imports, however, remain to be examined more closely. Do actors invest in ties before generalized exchange exists? How do they take a risk in a situation of uncertainty? In our view, actors may try to import exogenous structures but there is a limit to this process because the number of (compatible) identity criteria that each of us can credibly use is limited by preexisting constraints.

In the next section, based on a case study, we illustrate this point by specifying several social mechanisms (Stinchcombe, 1991; Hedström and Swedberg, 1998) that drive collective action in economic partnerships. Specifying such mechanisms goes beyond simple statements of embeddedness seeking to prove the economic efficiency of the existence of social ties, or 'relational capital'. These mechanisms spell out processes that are key to collective action, mainly exchanges of resources, control of commitment and oligarchic negotiation of precarious values. A good definition of such mechanisms exemplifies the usefulness of added behavioural assumptions in a structural approach to economic activities. It also provides new understanding of the relationship between the micro and macro levels of collective action, not just a criticism of the limitations of orthodox economic sciences in their approach to economic activity. In the following sections we sketch a definition of these mechanisms.

\section{SOCIAL MECHANISMS FOR COOPERATION AT THE INTRAORGANIZATIONAL LEVEL}

Framing the structural contribution to the study of markets and organizations through the notion of social mechanism goes beyond narrow structuralism. ${ }^{17}$ Examples of social mechanisms in organizations include solidarity (generalized exchange), management of status competition, control and rule enforcement, and 'constitutional' processes (that is, redefinition of the rules of the game). An old sociological tradition focuses on social mechanisms supporting and enhancing economic performance, beginning with Durkheim in 1893 and now strongly established (Burt, 1992; Macaulay, 1963; Bourdieu, 1980; Coleman, 1990; see Flap et al., 1998, and Gabbay, 1997, for a review). Here maximizing performance not only means improving technology, product and organizational innovation, managerial coordination or financial management. It also means maintaining the specific local constellations of relationships that are the basis of social mechanisms and that help organizations to solve problems of coordination. ${ }^{18}$ 
This conception of a structural approach of collective action in terms of social mechanism helps in this analysis of exchange, control and social change. It is compatible with a theory of action such as that outlined above. In this section, we illustrate this approach at the intraorganizational level by using a structural study of a professional partnership. This study offers a description of the three generic social mechanisms that are needed to sustain the collegial form of collective action (a multiplex generalized exchange system, a lateral control regime, and the process of negotiation of precarious values). Looking at such mechanisms helps in understanding how an organization provides structural solutions to problems of collective action. These mechanisms and their efficiency have been examined in a medium-sized northeastern US corporate law partnership (Lazega, 2001a). Some characteristics of this firm made it easier to study these mechanisms: in particular, partners had locked themselves in a very cooperative situation and constraining structure: they have adopted a compensation system that helps (or forces) them to take a long-term view with regard to cooperation and solidarity; they can expel one of their own only if there is near unanimity against him or her. They also belong to a profession that is usually favoured with monopoly returns, thus loosening the relationship between efficiency, performance and scarcity of resources.

The firm can indeed be seen as an exchange system for various forms of resources, and members as (broadly conceived rational) status competitors managing and accumulating these resources needed to work and survive in this environment. The production process is based on the use of social ties in a generalized, multiplex and multilevel exchange system. ${ }^{19}$ This system is shown to rest on rules of partner selection and to be effective at cultivating and mitigating status competition among members. The analysis of the ways in which these resources are bartered leads to the identification of informal entities such as niches that are shaped by members' use of the formal structure of the firm. The effects of relevant differences in members' selective choices of exchange partners such as hierarchical status (partner/associate), speciality (litigation/corporate), office membership, gender and law school (Ivy League/non-Ivy League) are examined to confirm the emergence of these social niches. The existence of these entities is then used to provide insights into the way collegial organizations find structural solutions to additional key problems: first, motivating tenured partners; second, quality control; third, opportunism in the form of free-riding; and fourth, firm integration.

The firm can also be seen as a control system (against behaviour considered to be opportunistic, such as shirking) in which issues of cost of control and rule enforcement are as central, if not more so, as in any form of collective action. A structural perspective also helps focusing on the relationship between status and control of enforcement of decisions made by the partnership. This 
issue is of particular importance in formally egalitarian bodies in which practitioners are all nominal equals and interdependent. Free-rider problems quickly arise in such settings because even a member who did not contribute effectively to the firm's revenues imposes a cost on the organization as a whole by reaping the benefits of membership (Olson, 1965). As a consequence, monitoring and policing, especially early graduated sanctions, are considered to be particularly important for ensuring that members' individual commitment to contribute remains credible. A second-order free-rider problem arises as well: the problem of who will bear the costs of monitoring and enforcement of previous agreements among the formally equal members (Heckathorn, 1989; Oliver, 1980; Yamagishi, 1986). In such contexts, hierarchical control being relatively weak, there is reluctance, at an early stage, to use formal procedures against colleagues to overcome free-riding and maintain solidarity. Direct command or use of administrative hierarchy are not considered appropriate means for exercising control because professionals have many ways of neutralizing formal authority (Gouldner, 1954; Freidson, 1975, 1986; Bosk, 1979.) In fact, early monitoring and sanctioning in collegial organizations also rely on specific forms of interdependencies in the exchanges of resources to protect overall prosperity against individual opportunism or parochial interests. Knowledge of such relational constraints helps to understand how members try to keep early monitoring costs low, and themselves motivated to carry on monitoring and sanctioning each other. These constraints take the form of a lateral control regime (Lazega, 2000b) that is also part of firm social capital in Coleman's sense because it helps peers find an early solution to this second-order free-rider problem in formally egalitarian interdependent groups. In this regime, status, particularly that of members called 'protectors of the common good', is shown to be central. Thanks to this social mechanism, individuals find it advantageous, credible and safe to pursue contingent commitment to rule compliance and mutual control.

Beyond economic performance (Lazega, 1999b), the exchange system can also be shown to be useful in maintaining firm integration, that is, in dealing with many centrifugal forces threatening the organization (for example, disputes about sharing profits, secession of rainmakers - partners controlling access to important clients - and their more or less permanent team to another firm, status competition in the work process, disputes between subgroups representing different offices or specialities). The study shows that members of a collegial organization have an interest in maintaining a stable oligarchy, a subset of members with various form of status. Oligarchs are often under pressure not to fight. They are all the more appreciated in that they do not raise controversies, keep a low profile and present their agreements as renegotiable. Multi-dimensionality of status comes usually with processes that help the 
collegial organization maintain a balance of powers between oligarchs. This is the case at this law firm, where economic and administrative powers are separate, informally but in a strong structural way. This allows two forms of solidarity and integration to coexist, one based on a 'welfare system' of bureaucratic distribution of work, the other on an informal and 'clientelistic' distribution. Each form of solidarity (welfare and clientelistic) is made possible by members with different forms of status in the organizations ('minders', who are more responsible for the long-term time frame in the organization, and 'finders' who bring in and control access to new clients) that are kept dependent upon each other. In many ways a collegial organization replaces an autocrat with a set of oligarchs who prevent each other from accumulating enough resources to be independent. Collegiality (thus called polycracy) presupposes the interdependency of oligarchs. Cohesion in the oligarchy is reached by a balance of powers and integration à la Montesquieu (Lazega, 1992b, 2000a; Kuty, 1998). Maintaining heterogeneity and interdependence of forms of status is often the condition under which rivalry among oligarchs leads to equilibrium.

Finally, this structural approach also helps us to understand the "constitutional' process of such collective actors by looking at their members' negotiation of precarious values underlying policy options and derived rules of social exchange. As seen above, in the section on symbolic interactionism and roles, members of an organization do not have rigid overarching 'common values' (Crozier and Friedberg, 1977) and derived rules. For example, in decisions on recruitment through cooptation, peers often reach a conflict between loyalty (typically clientelistic criterion) and excellence (ideally bureaucratic criterion). Managerial, professional and entrepreneurial ideologies can conflict in the redefinition of organizational rules and policies. Actors, if they want to win, sometimes have to redefine their priorities in terms of values (Friedberg, 1993). In a collegial organization, for example, partners feel free to develop their own conception of professionalism. They calculate their interests, but they also 'negotiate' their values (Kuty, 1998). They must accept debates concerning professionalism even when members with superior economic power (for example controlling access to large and lucrative clients) try to impose their own hierarchy of values, their own rules of the game, their terms for multiplex exchanges. In particular, given that no member can have the last word once and for all in such discussions, a modus vivendi is usually established among them. A structural approach can help understand, in part, this modus vivendi.

A structural approach looks at the social mechanism helping members control this constitutional process in the firm, that is, the renegotiation of the rules of the game. A precarious value (Selznick, 1957) is one that is essential to the viability of the collectivity but in which most members may have no 
direct stake. Examples of precarious values include, in collegial organizations, hierarchical authority and professional ethical principles. Subunits fight for the particular values entrusted to them and may continually redefine them to assert their priority over potentially competing values. Client satisfaction, internal coordination, innovation and quality of professional knowledge, societal needs and employee interests would not be defended or promoted if not represented by powerful subunits or members to whom the values in question are paramount, and the organization as a whole would be the poorer (Simpson, 1971).

This social mechanism helps collegial organizations solve the problem of endless deliberation about norms and values, and thus about firm management policies regarding issues such as compensation, peer review, work intake and assignment, marketing, and many others. ${ }^{20}$ It is shown to make use of the multi-dimensionality of status ahead of the deliberations themselves. It consists in authorizing specific forms of status consistency so as to prevent certain legitimate values from being later defended forcefully by the appropriate oligarchs. In effect, regulatory decisions are also made from within the organizational exchange system. The social mechanism of definition of rules is based on a selection of bi- or multi-status oligarchs who play a leadership role by defining priorities. ${ }^{21}$ Their selection brings into the deliberation only oligarchs who have several forms of status and represent several precarious values, thus able to give priority to one of these forms without disqualifying the others. The negotiation of precarious values, or the emergence of a priority value, requires a cohesive core of multi-status oligarchs clearly identified with such values and in a position to defend their rank with their peers, if not to prescribe them to each other. In short, the debate about precarious values uses in a constraining way the heterogeneity of sources of status observed by the classics. Structure mediates between interests and values because oligarchs can promote some norms and conventions while playing down the importance of others (Lazega, 2000e).

This is also part of the politicization of exchanges as defined above and as part of cumulating power in the sense of capacity to set premises and to define terms of exchanges. Structural approaches remain limited as long as they are not associated with the study of forms of politicization of exchanges allowing for the circulation of resources, that is, the choice of exchange rules among members. This work, however, goes beyond the capacity of narrow structuralism to use qualitative methods. Rules surely have an endogenously dynamic dimension. They develop within a relational structure and they themselves have an effect on the evolution of these structures, especially through their influence on the selection of exchange partners (see Kellerhals et al., 1988 for an example). In this field, much remains to be done. 


\section{SOCIAL MECHANISMS OF COOPERATION AT THE INTERORGANIZATIONAL LEVEL IN STUDIES OF MARKETS}

At the beginning of this chapter, we argued that the social mechanisms characterizing collective action at the intraorganizational level, as well as their modelling, may also characterize collective action and coordination at the interorganizational level. Beyond early structural approaches that were often limited to statements of embeddedness, the same broadly conceived structural approach can be used to look at organizations as actors trying to structure their environment and shape their opportunity structure, and at the derived mechanisms of cooperation.

Specifically, we argue that the collegial form of organization (and its network analysis) offers models for examining the social organization of a market economy, an economy that is not bureaucratized by state planning, especially for the coordination of activities among interdependent entrepreneurs. This does not mean that the state does not intervene in such an economy, but that its interventions are now looked at as competing with those of all the other stakeholders of the economy, including small and medium-sized business groups, large multinationals, independent or supranational watchdogs and regulatory bodies, and many other organizational entities. In this organizational society, the state still wields strong powers - not least power of legitimate violence - but so do some of the other entities that play an entrepreneurial role or control the circulation and allocation of enormous amounts of resources. In addition, there are many levels of cooperation between the two ideal-type models of collective action, as well as within each type. Levels of involvement in cooperation go from temporary but multiplex contracts (such as that characterizing services industries) to strong alliances and eventually mergers.

Organizations, whether public administrations or private businesses, do not conduct their affairs as isolated units. Their resource dependencies (Salancik and Pfeffer, 1977) force them to form cooperation ties with other organizations, and these relationships are expressed by more or less clear legal and social boundaries. ${ }^{22}$ Recall that Levine and White (1961) already framed interorganizational relationships in terms of exchanges of resources and resource dependencies (Aldrich and Marsden, 1988). Resources exchanged through multiplex ties at that level can be learning goods, services that may or may not come attached to financial credit and so on. This view underlies Harrison White's seminal work $(1981 b ; 2001)$ in which transfers and exchanges of production-related resources are the defining features of production markets. It is the basis of the sociological approach to markets as social institutions facilitating exchanges without being reduced to price definition mechanisms (for a summary, see Swedberg, 1994). 
Is this extension to cooperation at the interorganizational level (of a reality previously examined at the micro level) acceptable? To what extent are higher order entities such as organizations 'rational' in a broad sense? Individuals, when they represent organizations and make decisions on behalf of them, make a special effort to be efficient cost-benefit maximizers. But do their organizations select 'identities' and get involved in 'social' exchanges in order to shape their opportunity structure? Does it make sense, at that level, to get involved in identity politics, to join meso-level niches for better and easier access to resources? ${ }^{23}$ Does cooperation at the interorganizational level rely on any form of social discipline that can be differentiated from a purely utilitarian attitude? The same question applies to competition for status, that is, for better control of the terms of exchange and prices of resources, or for rule enforcement and regulatory clout. A positive answer could make it worthwhile to identify multiplex social mechanisms for collective action because it would provide a new vision of productive systems in regions, sectors or other levels. It would lead structural approaches towards a more general theory of collective action at the meso and macro levels. There is certainly no scale invariance with regard to rationality and social phenomena, but it is nevertheless possible to assume that, just like individuals, organizations follow similarly politicized principles when making decisions concerning transactions with partners such as other organizations (Raub and Weesie, 2000). This, however, is a true challenge for a broadly conceived structural economic sociology. Nevertheless, elements of answers to the above questions - the first building blocks of this structural research programme in economic sociology - are available already.

All exchanges between organizations are not necessarily 'purely' market exchanges. For many years, research has been conducted on the ways in which individuals working in or running such social settings, even if they often tend to behave as 'rationally' as possible (by definition of the organization of work), also use them for purposes that are not immediately and directly connected to purely focused production activities. In many such situations, cost-benefit calculations, with regard to many activities, although mechanically performed, have a fictitious dimension. For firm A, putting a precise price tag on a specific $R \& D$ operation involving cooperation between its own scientists and that of firm B is formally possible, but it is a bet that very often does not reflect any clearly defined costs or market value for the outcome of this operation. For the same companies, putting up a million Euros to support a political campaign is also an expense measurable in monetary terms, but the amount of this form of investment cannot be reduced to a price as usually defined on a market (again, a rational value that can be associated with a specified outcome). Many such expenses and investments cannot be traced back to clear cost-benefit calculations. The price of trying to structure one's environment to get 'Pareto protection' is not easily defined. To look at them, in part, 
as forms of relational investments or social exchange is useful in the sense that such practices, which are important for economic activity, have a logic that differs from the price mechanism. Our point is that this logic can easily be compared to that of social exchange, and lead to the niche building and status competition examined above.

Although the conditions under which such exchanges can be defined as barter are not entirely spelled out yet, it is helpful to assume that they can be and that organizational politics include learning the mechanics of social exchange: this perspective brings together various contributions by structural sociologists in that domain.

\section{Social Niches and Status Competition at the Interorganizational Level}

Actual structural network studies of multiplex ties in interorganizational 'fields' (DiMaggio, 1986) are rare because such data are sensitive and strategic. Visible elite family ties, for example, no longer constitute a strong basis for social discipline in the business world, as they did in 19th-century forms of capitalism (Berle and Means, 1932; Chandler, 1977). Therefore, in order to look at contributions, at the interorganizational level, to the broadly conceived structural approach outlined here, it is useful to focus directly on pioneering work echoing more or less directly our reasoning about niches and about status. Concerning niches, ${ }^{24}$ DiMaggio (1986) exhorted organizational analysts to reason in terms of observed patterns of exchange relations. As mentioned above, a few exceptional studies in the 1980s - pioneering in their analyses of transfers and exchanges of resources - were conducted with this preoccupation in mind (for a presentation of their place in the history of market analyses, see Swedberg, 1994). For example, it is possible to read Berkowitz's work (1982, 1988; Berkowitz and Fitzwilliam, 1995) as a first approach to niche building. As seen above, this author combines control (interlock ties) and ownership (capitalistic) ties among companies to provide early network modelling of market structures. He defines new entities called 'enterprises', then 'market-areas' as a new kind of clustering of production activities in which these enterprises operate and get new business footings. Although he does not provide much understanding of how these 'enterprises' operate, these new contours also offer an original overlay of competitive markets at various levels of complexity, one that is separable from more standard technologybased approaches.

Studies of business groups (including conglomerates such as Japanese keiretsus and Korean chaebols) could also be used as proxies for systematic detection of social niches. Selection of exchange partners may be studied through choices of suppliers, subcontractors or distributors that are in themselves investments in relationships. Granovetter's (1994) programmatic text 
on business groups also exemplifies this structural approach to interorganizational ties. He considers business groups to be interorganizational entities in which exchanges of resources are dense and multiplex, but who also raise 'private', non-tariff barriers to economic dealings with the 'outside' of the cartel, thus restraining trade. There are forms of particularistic solidarity, ways of giving premiums to loyalty, that are more or less visible. Sharing costs of exploring new markets, lower financial costs of raising capital, sharing personnel and so on are indicators of such forms of solidarity even among competitors. Granovetter (1994) offers a research programme on business groups, which he defines as formal and informal federations of companies that constitute a more or less coherent social structure. ${ }^{25}$ He emphasizes the fact that in many countries the choice between a business group federation and consolidation is affected not only by economic contingencies, but also by political and symbolic factors. Ties between organizations include commercial transactions, but also mutual ownership, solidarity ties based on religion, political allegiances, ethnicity and family or regional ties. Granovetter includes moral constraints as a component of the social discipline underlying economic transactions in such business groups. ${ }^{26}$ Such formal and informal ties allow them to become more than the sum of their parts. Coordination depends on this embeddedness of economic decisions in social ties. Systematic data about these phenomena are obviously missing.

In effect, in business groups, for example, connected partners both force and help their managers to deal with and share common risks. It is at the level of groups that real risks are taken in business strategy, but only when member organizations are mobilized and committed to carrying out such policies. These ties can be analysed as multiplex networks of easier access to capital, information and personnel, but also strategic advice with or without transactions or common responsibilities. These resources give a concrete meaning to the term 'group', even when multiplexity is reduced compared to what it can be at the intraorganizational level. This presupposes the capacity to detect meso-level forms of bonded solidarity that represent forms of short-term rationality embedding themselves in longer-term rationality on which they depend. Studying groups is not easy: these resources must be sharable and appropriable ones, both at the national and the international levels (Boccara, 1999a, 1999b). Unpredictability and uncertainties are delegated or passed on to subcontractors or to certain categories of employees; those at the lower end of the dumping chain (whose labour contracts become increasingly 'flexible') incur the maximum of risks and costs. The social structure is thus key to showing a process of risk allocation. ${ }^{27}$

An empirical phenomenon that provides an opportunity to look at niches based on ties with exchange partners is the phenomenon of strategic alliances. This topic has received considerable attention in the organizations and business 
strategy literatures (for example, Gulati, 1995; Uzzi, 1997). Firms establish alliances because they expect benefits from access to resources provided by such ties. Organization scholars have been particularly impressed by the learning advantages of these alliances which provide firms with fresh know-how and skills (Kogut and Zander, 1996; Powell et al., 1996). However, the existence of 'knowledge niches' has not been examined as an object in a social and relational space, only as a phenomenon characterizing a 'technological space' (see below). ${ }^{28}$

From the perspective outlined here, it is worth arguing that three approaches to the existence of social niches remain underdeveloped. The first is concerned with the role of state administrations (and associated corps d'Etat in countries such as France) in the creation of social ties among executives. The second is the role of the non-profit sector (Anheier and Seibel, 1990), including business schools, in the creation of such ties, a role that has not been fully exposed. The third is that of illegally (trust) cooperative ties in which information and commitments are exchanged (Baker and Faulkner, 1993, Baker et al., 1998). Looking at such niche-building contexts that bring together businesses for various purposes should be a productive area of research.

The second concept that could be used to account for social mechanisms at the interorganizational level is that of multidimensional status competition. The concept of status has been only partly exploited in a broadly conceived structural approach to markets. It is still not very clear how status exists at the interorganizational level, at least from a perspective combining social and market exchange. Studying market uncertainty, Podolny (1993, 1994; Podolny and Stuart, 1995) uses this traditional concept to account for the selection of business partners. Firms use evaluations of status to signal quality and select exchange partners. Partners with status inspire confidence, attract risk-averse customers and are able to define favourable terms of exchange with lesser status partners. This use of the concept, however useful at early stages of structural analyses of markets, remains vague because the various dimensions of status are not clearly defined and compared; power generated by the concentration of various kinds of social resources is neglected. In spite of its conceptual weakness, this work nevertheless shows how difficult it is today to look into interdependencies between entrepreneurs, even at the descriptive stage, and how useful it would be to identify such forms of status more clearly. This difficulty is even greater at the explanatory level required to account for the social mechanisms of cooperation. Data for studying these social mechanisms at the interorganizational level are scarce. Recall that structure is defined as regularities in multiple resource interdependencies among entrepreneurs with a business footing; interdependencies are always multiplex (defined for several resources) and multilateral. 
Finally, the relationships between niche seeking and status competition at the interorganizational level deserve special attention. Just as endless brainstorming fuelled by status competition among peers is dealt with (kept under control) by oligarchs, the latter can also replace dysfunctional markets with more viable ones, although more brutally at that level (Lazega, 2000e). For example, it is sometimes indispensable for large companies to agree to impose a common technological standard without which markets would unravel. At the interorganizational level, the effects of social niches and those of status and power may not be combined and balanced as efficiently as they can be at the intraorganizational level, because corporate actors are run by individuals who are trained to make particular efforts to be as cost-benefit maximizing as they can. Corporate leaders still look for social niches, using identities, or membership in ethnic groups (Saxenian, 1994), but this does not necessarily predispose them to lenient behaviour when survival is at stake. The fact that oligarchs' power may be more brutal (than it is at the intraorganizational level) does not identify their interventions with those of a formal hierarchy such as a state administration's. At the interorganizational level, distinctions between status (Weberian Herrschaft) and raw power (Macht) matter less because power here is less often confronted with or challenged by various forms of status. Distinctions such as that used by Hannan and Podolny (legitimacy produced by endorsement) are not always necessary when power and several forms of authority are concentrated in the same hands. In this situation, there is not much social exchange: calculating strategies anticipate the decisions and movements of asymmetrically distributed resources generated by threatening repositionings of oligarchs (big firms).

\section{Social Mechanisms at the Interorganizational Level}

Commonsense accounts of governance of business often have it that, at the interorganizational level, the notions of private resources and relation-specific investments seem to be less relevant than at the intraorganizational level. But this statement is highly questionable. High-level managers need multiple resources to interact with the interorganizational environment and they usually do not rely exclusively on resources provided by the formal organization itself (indeed, they are often hired for their own personal network). The general idea that studies of relational structures should go beyond the description of embeddedness and account for social mechanisms that are grounded in exchanges of resources among firms can actually be found in Granovetter's (1985) own work and in a more recent preoccupation with the 'governance benefits' of embeddedness. ${ }^{29}$ Current 'embeddedness studies' sometimes provide glimpses of such mechanisms. Given the constraints on data collection, such studies remain mostly at the dyadic level and are unable to reach (as intraorganizational studies sometimes do) the structural level. 
At the dyadic level such studies are different from most economic research on the question of inter-firm arrangements promoting governance benefits for firms in their interorganizational transactions. This economic research focuses on how formal 'governance' arrangements, such as contracts, hostage taking or hierarchy, enable exchange partners to capture gains through trade (Williamson, 1996; Dyer and Singh, 1998; Raub and Weesie, 1996; Batenburg et al., 1997). By contrast, recall that other theories argued that governance benefits are achieved through the embedding of commercial transactions in social attachments and networks (Granovetter, 1985, 1994). The latter studies are conducted with thorough investigation of the formal economic structure of the market (number of firms, concentration, market shares, quality niches, intermediaries and so on). They offer the equivalent of the above-mentioned glimpses because they show that social embeddedness offers a useful account of how social life matters, at the dyadic level, for economic benefits in markets. Using measurements of social embeddedness in a financial market, Uzzi (1999) shows that firms get easier access to loans and lower interest rates from mid-market banks when entrepreneurs maintain social ties to a privileged bank officer and arm's-length ties to other bankers. He argues that embedding commercial transactions in social attachments and networks facilitates dyadic exchanges by initiating 'self-organizing governance arrangements' that operate through expectations of trust and reciprocity and access to private knowledge. At the level of the bank-firm tie, increased embeddedness enhances governance benefits. Firms' networks composed of a complementary mix of embedded and arm's-length ties are said to produce optimal governance by reducing the need for costly formal governance of loan contracts.

Another example of research that comes close to identifying social mechanisms based on niche seeking and status competition is that of Podolny and Stuart (1999). Building on their previous work (1995) on patents citations, they show that position in what they call a 'technological space' can drive alliances and their performances in specific industries. ${ }^{30}$ This technological space is thus assumed to have its own dynamics, ${ }^{31}$ which, together with firms' considerations of relative 'status', would drive the evolution of the industry. This evolution is thus linked to considerations of power (that are considered social structural in that they are different in nature from technology). Although it assumes the existence of an exchange system (of which alliances would be an indicator) between firms, this research does not examine it as a multiplex and structural phenomenon. Rather, it switches to a different (more ecological) conception of 'niche' to account for survival of firms in the industry. Podolny et al., (1996) develop a conception of an organization-specific niche (defined by 'crowding' and 'status' - itself built from citations of an organization's patent portfolio, not through analysis of dense and multiplex exchanges of resources) in a technological network to show that it can enhance the firm's 
growth and survival chances. ${ }^{32}$ This approach loses even White's insight about the importance of structural equivalence (with respect to the pattern of ties to upstream and downstream organizations) for niche building, not to mention the importance of any form of density in the exchanges between firms. ${ }^{33}$ Nevertheless, there is much to learn from these studies in terms of looking at outcomes such as survival, growth rates and innovation as effects of niche building and status competition, as described above.

The importance of niche seeking and status competition for control and enforcement of regulation has largely escaped analysis up to now. Status competition may make sense at the interorganizational level even in an increasingly oligarchic (monopolistic or duopolistic) forms of competition. Niches, often identifiable through either corruption or violation of antitrust laws, make sense at that level when rents cannot be extracted from a monopolistic position. The balance between status competition and niche seeking is in itself the very stuff of competition policies that are attempts to regulate production and exchanges on markets.

More even than at the intraorganizational level, relation-specific investments between organizations raise the problem of sunk costs (when on party behaves opportunistically) and therefore social mechanisms, in addition to legal ones, are also needed here to deal with first- and second-order freeriding. For example, the issue of commercial justice can be framed in terms of formal external regulation (Hawkins, 1984; Reiss, 1984; Shapiro, 1984; Vaughan, 1983, 1996) or self-regulation (Lazega, 1994b, 2001a; Lazega and Mounier, forthcoming), but also in terms of more informal conflict resolution mechanisms (Macaulay, 1963) or private arbitration practices created by corporate law firms (Dezalay and Garth, 1999). The contribution of social ties (and derived niches and forms of status) to social control mechanisms in the business world remain, to our knowledge, poorly studied. Governance mechanisms in Williamson's (1996; also Raub and Weesie, 1993) sense only scratch the surface of all the processes that help interdependent entrepreneurs monitor and sanction each other before (or through) resorting to well-defined but costly court procedures (Cheit and Gersen, 2000; Dunworth and Rogers, 1996; Macaulay, 1963; Rooks et al., 2000) and how society attempts to exercise control over their activities. ${ }^{34}$

Finally, since niche building and status competition are inseparable from a politicization of economic activity, attention has also focused on political management of economic activity, but in a way that does not yet provide new general insights on political economy. Neoclassical economics with its ideology of pure competition has often permeated studies of markets. White's and Burt's approaches helped question such views by connecting reasoning in terms of network analysis with ideas on monopolistic competition. But they do not focus on how economic actors such as interdependent firms spend time 
and resources structuring their environment so as to escape competitive markets. As well described by Pareto and Schumpeter, entrepreneurs as political 'courtesans' try to dump market competition on others, and to look for niches in which rents and discounts are available. If organizations follow this logic as well, it makes sense to assume that they all vie both for collusion (Baker and Faulkner, 1998) with specific suppliers, subcontractors and consumers, and for forms of status that would both attract clients and give them power to negotiate terms of trade with partners outside the niche. Markets are often rigged and constructed in interorganizational contexts in which power is usually in the hands of a very politicized establishment. In this establishment, actors recognize each other or identify with one another (using identity criteria) and act politically to keep their shared power, instead of (or at the same time) competing, for example, on the basis of innovation.

However, unsurprisingly, data are also missing to test the effect of such behaviour and check for the existence of the self-regulatory social mechanisms underlying transactions among firms. The influence of niche seeking and status competition on regulatory work is also a domain that is underresearched. Institutional economics and sociology have often looked at contexts in which economic activities and competition take place as legally and culturally defined (Hirsch, 1997). Markets cannot emerge without appropriate legal property rights, and also many derived rules such as bankruptcy laws, that are defined and negotiated in a political sphere (Carruthers and Halliday, 1998). Fligstein and Mara-Drita's (1996) work on the construction of the European common market fleshes out this idea of politically constructed competition, with an important role played especially by the state. Fligstein distinguishes stages of market development, calling attention to endogenously formed institutions as sources of order, echoing White's approaches to niches and adding focus on firms 'conceptions of control'. But truly structural studies of the regulatory process (using measurements of multiple forms of status and power in complex oligarchies negotiating the rules of the game) are almost non-existent.

The effect of resource dependencies on the capacities of some actors to redefine the rules, the terms of exchange and priority values, has barely been examined, with the exception of studies of lobbying such as that of Laumann and Knoke (1987) and Pappi and König (1995). Criticism for such a lack of interest for data collection has long been around (Fligstein, 1990; forthcoming). Studies of intraorganizational relational structures have been used to look at the reasons for which some businesses try to redefine the rules of their competition (Lazega, 1994b) as they apply to their sector, for example rules about conflicts of interests in corporate law services. Professional firms use organizational devices to reassure the market about the ethics of their economic behaviour. Another example of regulatory effort is provided by 
struggles to impose a standard upstream of production (not so much for market share in mature markets). Such standards can even be called for by first- and second-rank subcontractors who prefer universal standards even if they impose a cascade of new adjustments and constraints. But very few structural studies have been able to show how organizations participate in shaping their normative and regulatory environment. Concerning the study of that generic mechanism, which is the most visibly politicized of all such mechanisms, almost all remains to be done. The dynamics that it calls for are only barely perceived.

We know that companies pay large campaign contributions to ruling political parties (Useem, 1984; Carruthers, 1996). Lobbying studies mentioned above, while examining the influence of interorganizational networks on policy making (Laumann and Knoke, 1987; Pappi and Koenig, 1995; Stokman et al., 2000), and on attempts to use and impose their industry customs and rules on others (Swedberg, 1993), show how economic policy is partly shaped by lobbying practices of large companies and industries. This is, however, where a more complex behavioural assumption about corporate actors (such as that used above when outlining a theory of politicized appropriateness judgment) is needed to make progress. A broadly conceived structural approach must focus on such regulatory activities much more than it has up to date. In our view, this is precisely where conventions and structures combine (Lazega, 1999a, 2001a). In particular, various dimensions of economic status need to be differentiated in order to look at various forms of influence in the regulatory process.

In sum, pioneering structural studies of interorganizational ties suggest the feasibility of more systematic examination of social mechanisms and their role in the economy, but, owing to lack of access to data, very little has been achieved in that respect. Studies in progress nevertheless illustrate the search for various forms of balance between collegiality and bureaucracy in different kinds of collective actors (Comet, 2001; Stofer, 2001; Varanda, 2001; Wattebled, 2001) producing both standardized and unstandardized goods, particularly by looking at the social mechanisms that help their potential or actual rival members in their efforts to cooperate.

\section{CONCLUSION: A PERMANENTLY SHIFTING BOUNDARY BETWEEN BUREAUCRACY AND COLLEGIALITY AT THE INTERORGANIZATIONAL LEVEL}

In this chapter, we have sought to evaluate the extent to which it is possible to reason at the interorganizational level in the same terms as at the intraorganizational level. Do interdependent corporate actors get involved in multiplex 
social exchange and politicize their behaviour through niche seeking and status competition? If so, does this lead to social mechanisms such as those identified at the intraorganizational level? In that case, it would have many consequences in reasoning about policy, given the existence of macrosociological constraints that need to be taken seriously.

Switching from the intraorganizational level to the interorganizational level with the same theory is not an obvious research programme. Nevertheless, the ingredients of an 'extended' structural contribution to the study of markets and organizations, one that goes beyond the contribution of pioneering structural studies, was presented above. From this perspective, economic sociology does not need to start with the distinction of markets and hierarchies. It is based on a different conception of the economy, one in which it is too limiting to explain the emergence of collective actors such as organizations or groups of organizations as a result of a 'make or buy' decision based on the evaluation of transaction costs and what they would otherwise be on a supposedly unstructured market. Rather it is much closer to a strategic analysis of economic activity, and to political economy.

It is based on a conception of rationality that is broader than traditional rational choice. It includes economic calculus but integrates also symbolic reasoning allowing bounded solidarity and politicized exchanges of multiple resources, delegation of control and deliberation on precarious values. It allows for actors' attempts at shaping their opportunity structure at the (analytically speaking) meso level, whether inside or between organizations. In many ways, we would like to argue that it is a broadly conceived structural approach that can bridge the gap between economic and sociological approaches to coordination of collective action.

The specificity of broadly conceived structural studies is in their use of network analysis as a method for tracking and understanding flows and exchanges of resources, their control, and negotiation of rules commanding such flows and terms of exchanges. We argued that the models developed to analyse social mechanisms allowing for cooperation between interdependent entrepreneurs at the intraorganizational level can offer insights into, and hypotheses for, the study of interorganizational cooperation between interdependent entrepreneurs. Based on such an approach to economic activity, the strong difference between markets and organizations tends to be replaced by the dialectic interplay between mechanisms characterizing bureaucracy and collegiality in each of the two contexts. These mechanisms are triggered by selective investments in relationships within social niches and for status competition. They represent a meso-level social and cultural discipline that underlie both intraorganizational and interorganizational coordination.

Every organization and/or interorganizational system, however, is different with respect to the temporary balance between bureaucracy (that shapes 
collective action for standardized, more repetitive, production) and collegiality (that shapes collective action for unstandardized, more innovative, production) that it can achieve. One of today's most intriguing issues in theoretical economic sociology is perhaps to figure out a typology of equilibrium points between the two models. Because real-life organizations are different and because they change, the boundary between the two is permanently being redefined, and these kinds of balance are moving targets. A theory of these equilibrium points can therefore only be developed by using longitudinal approaches and analyses of the dynamics of organizational and interorganizational structures.

Current research insists on multiplexity, on constraints coming from multiple relationships between exchange partners, whose recurrent interactions compose relational structures maintained by sanctions and helping in enforcing formal contracts. These contributions use multiplex databases very little. A quick review of the literature on this issue shows that economic sociology develops very slowly in that respect. This rhythm is due to difficulties related to systematic data collection, particularly on economic transactions (buying and selling) between sets of organizations (such as groups, or local or regional industries, or 'market areas' in Berkowitz's sense, or more standard sectors). Measuring commercial ties is difficult; combining such measurements with systematic information on social ties among actors is even more difficult. Accounting and social data are strategic to companies (especially with respect to competition and regulatory authorities). Therefore social niches and status competition - and derived mechanisms - are not easily detectable empirically. Most of the work therefore remains to be done in that respect. In particular, more research is needed on actors' investments in social exchange and on the social mechanisms of cooperation (among individuals or among organizations) that such investments trigger. In addition, generic mechanisms are connected to each other: the last two (control and regulation) are attempts to protect the first: bounded solidarity between interdependent entrepreneurs.

This broadly conceived structural approach, and especially the challenge of using multiplexity in intraorganizational and interorganizational studies, has the potential to renew economic sociology. Although many 'embeddedness' studies assert the importance of social ties and 'gifts' for individual economic performance, the embeddedness framework has often justified lack of efforts from researchers to look for complete networks and structural solutions provided for basic problems of collective action such as solidarity, control and regulation. Only complete network data of specific intraorganizational and interorganizational systems, at several points in time, can provide systematic ways of linking micro and macro levels of analysis by describing relation-specific investments and social mechanisms derived from them. Unless such methodological efforts are made, multi-level structural studies of organizational change and evolution of 
markets will remain even scarcer. A thorough understanding of the organizational society and its social mechanisms will not be developed. Organizations and markets must be held accountable, to some extent, for some of their externalities and social costs. Much more remains to be done in order to fulfil this goal.

\section{NOTES}

1. A first draft of this paper was presented at the 1998 Cnrs Summer school on 'Markets and Organizations', at the Maison Suger in Paris. It was revised for presentation at the Seminar of Economic Sociology at the Maison des Sciences de l'Homme, Nantes, November 2000, then at the Seminar of Economic Sociology at the University of Paris IX-Dauphine, January 2001, and finally at the Journées du Clersé on 'The Social Organization of the Economy', University of Lille 1, June 2001. We would like to thank the organizers of these events as well as Sébastien Delarre, Alexis Ferrand, and André Torre for their comments on a previous version.

2. We do recognize (Lazega, 1996) the heuristical value and usefulness of this distinction for economists opposed to the neoclassical dogma, from Williamson (1975) to Favereau (1989).

3. Order imposed by a tightly connected oligarchic banking system can sometimes have the same effect on society, especially when the state delegates some of its power of legitimate use of violence (Lazega and Mounier, forthcoming).

4. For general network analysis, see Wasserman and Faust (1994). For the specific network models that test for the existence of social mechanisms of generalized exchange, lateral control and self-regulation in a collegial organization, see the references to our more technical papers in the bibliography.

5. Several papers provide overviews of this early work (see, for example Swedberg, 1994; Lazega, 1994a) and demonstrate how useful network analysis combined with even this minimal theory of action can be to economic sociology and its many substantive topics.

6. Burt (1988) observes stability at the ultimate macro level of aggregation using Leontief input-output tables of national accounts (where the organization is lost as a unit of analysis), markets tend to be stable in the social structure of production relations with suppliers and consumers. In his view, for example, multiplexity of ties (or resource dependencies) between organizations does not play any role in the mechanisms that account for stability in markets. This stability is conceived of as entirely 'structural' without any behavioural assumption at that level of aggregation.

7. For a detailed presentation of White's market models, see White (1981b, 2001), but also Eymard-Duvernay and Favereau (1990), Biencourt et al., (1994a, 1994b, and Chapter 6 in this book). For an analysis of the effects of introducing uncertainty about quality of goods in the analysis of economic activity, see also Karpik (1989).

8. This symbolic activity may be partly construed as a form of interpretation, as conventionalists understand this term.

9. On the relationships between network analysis and strategic analysis, see Lemieux (1982) and Lazega (1994a).

10. A generalized exchange system refers to the existence of cycles of postponed and indirect reciprocity. In the case of organizations, cycles are often short, involving only three or four persons; nevertheless, they indicate the existence of a form of bounded solidarity and social discipline.

11. A social niche is not necessarily a group because it does not always have the legitimacy that would be granted to an independent entity by an outside authority. The organization can recognize the importance of niches for efficient circulation of resources, but it does not favour the emergence of detachable subunits. Just as a social niche can be either a shelter or hell for an individual member, it can be an advantage or a threat for the organization that encompasses it (Lazega, 2000a). 
12. This conception of the relationship between rationality and protectionism is entirely compatible with Pareto's approach to entrepreneurial activity, except that it does not consider it to be a 'residual' form of activity.

13. On the relationship between identity, appropriateness judgments and contextualized behaviour, see Lazega (1992a; 1997).

14. For additional insights into cooperation as routine transfers or exchanges of various kinds of resources, see Bearman (1997), Breiger and Ennis (1997), Cook (1987, 1990), Ekeh (1976), Flap et al., (1998), Galaskiewicz and Marsden (1978), Gouldner (1960), Granovetter (1994), Han and Breiger (1999), Lazega and Pattison (1999), Lin (2001, 1995), Levi-Strauss (1949), Raub and Weesie (1990), Saxenian (1994).

15. As shown by Festinger (1954), the comparisons that matter for people are the comparisons with others most like themselves. Combination of criteria (office similarities, speciality similarities, hierarchical status similarities and so on) push members to compare themselves to same niche people.

16. It is not our purpose to assume that status competition is omnipresent in society. In many arenas, especially when production is routinized, actors do not try to accumulate resources and forms of status, thus accepting bureaucratic formal hierarchy. But at the interorganizational level, among interdependent entrepreneurs, such a competition, although limited by niche seeking, is in itself an instrument for the definition of terms of exchange, and therefore unavoidable.

17. The use of the notion of social mechanism is meant to convey a criticism of the use of the word 'governance', which overemphasizes the capacity of management to control collective action.

18. One feature characterizing this network approach to social mechanisms compared to many early ones is that it takes into account multiplexity in a much more systematic way. This accent on several types of resources leads to a more precise understanding of power and interdependencies among economic actors participating in collective action being needed to describe social mechanisms. As an example, take the difference between the human relations tradition and the structural approach to relationships at work (Lazega, 2001a).

19. The combined use of structural analysis and rational choice approach leads to abstract concepts such as multiplex relationships. The word 'multiplex' qualifies a rich relationship between two persons. It refers to the fact that the two persons have a relationship in which they can transfer and exchange multiple types of resources (Wasserman and Faust, 1994). For example, two partners have a multiplex relationship because they are co-workers on many cases, because they also seek each other for advice in difficult professional situations, and finally because they also have social activities outside work together. From a structural perspective, this means that specific local and multiplex substructures of social ties must crystallize for members to be able to cooperate on a continuing basis in the context of wider collective actors such as organizations.

20. One obvious way of controlling the deliberation about rules is to marginalize or exclude some members from the reference group itself, that is from the collective that is perceived to be the best arena for interpretation and enforcement of these rules. As previously noted, racism and other forms of discrimination are never far away from all the mechanisms that are based on barter and particularism.

21. Constitutional change is not the only form of change that multi-status oligarchs can promote. They are also in a structurally advantageous position to promote new products because they can afford both to invest in an innovation and to lose from abandoning the production of 'old' products.

22. In many ways, the structural approach has attracted representatives of economics of organizations, often based on transaction costs economics (Williamson, 1975, 1981). However, the distance between the two approaches remains considerable. For example, in this presentation, we do not use the word 'network' in the sense of a separate kind of entity that represents a specific form of coordination of collective action between market and hierarchy, a third 'hybrid' form. Many authors have questioned the usefulness a of transaction costs approach. Eccles (1985) has shown that in some large organizations transactions (based on transfer pricing) may be more difficult and costly than outside the organizations. For a critique of this approach, see Lindenberg (1996) and Lazega (1996). 
23. In particular, one might object that, at the intraorganizational level, one finds a form of homogeneity between members and a focus on one common objective, two features that cannot characterize society at large. However, in our view, as in that of strategic analysis, there is not necessarily a greater heterogeneity of actors and of goals at the interorganizational level than at the intraorganizational level. Another objection to that approach is that relationships between organizations are less a product of a choice of exchange partners than at the intraorganizational level. In our view, however, the choices of partners and level of investment are not necessarily available to agents within organizations more than between organizations. Prototypical of such choices is the selection of subcontractors (Lazega and Mounier, 1999). Equally questionable is the idea that a relation specific investment and the notion of a private resource make less sense at the interorganizational level than at the intraorganizational level. As often stressed by embeddedness studies, managers need the multiplex resources to run their organization and create markets (White, 2001). They cannot count exclusively on the resources formally provided by their organization. Relation-specific investment still raises the problem of sunk costs (when one party behaves opportunistically) and therefore the social mechanisms of control are also needed (Raub and Weesie, 1993; Williamson, 1996). But these investments with requests for commitment from the others in the niche do make sense at the interorganizational level too.

24. It is important to mention again that the niche concept has been the object of important debates, at least at this interorganizational level. The first protagonist of this debate is Harrison White, whose niche concept represents a specified level of quality in a quality array helping consumers compare products and quality/price ratios. This is obviously not the same meaning as a densely connected subgroup in which members have multiplex ties to one another, although it is not entirely different insofar as such dense groups are also positions of approximately structurally equivalent actors (see Borgatti and Everett, 1992, for a dedramatization of the distinction between cohesion and structural equivalence). Extending White's approach, Burt and Talmud (1993) also use the niche concept. They do reason in terms of ties representing transfers and exchanges of various types of resources, but they are mainly interested in looking for elementary substructures (especially ones that represent the existence of 'structural holes' and derived opportunities) that make sense regardless of the type of tie. This represents a simplification of the structural approach, particularly with regard to multiplexity, one that earlier contributions did not accept. This approach remains untested and is different from approaches assuming density of resource flows within the niche. It is not necessarily different if niches are also dense, since internal density in positions can increase the level of approximated structural equivalence between actors. But stressing such ties would introduce arguments about cooperation, not about competition between members of the niche. Actually, in these studies, interorganizational ties are rarely measured as such, often derived from similarity along common characteristics (using similar technology, developing interdependent innovations).

25. Formally, business groups are not simply strategic alliances or consolidated conglomerates. They are sets of organizations connected for economic, social and political goals. Stable cartels could be considered business groups. Granovetter uses the example of Korean chaebols and Japanese keiretsus, in which many kinds, including symbolic, of resources circulate, and where individual companies keep a separate legal identity. These groups include sets of companies that are neither integrated in a single holding nor completely independent. They are collective actors that do not exist legally as one single entity and that are not identified in the official census (Strachan, 1976). Careful attention to groups in other countries yields similar observations. Such a network may be costly in terms of price, but it might also be efficient in the long term with regard to innovation, investments, personnel management and social costs. In addition, sanctions may include marginalization, but also illegal ones (sometimes carried out by mafias).

26. Granovetter thinks that such groups have characteristics of moral communities in the Durkheimian sense. Moral constraints may have integrative force for members who know what behaviour they are entitled to expect from each other, especially with regard to behaviour perceived to be opportunistic. However, the effects of moral forces are difficult to measure and to disentangle from those of economic calculations. 
27. This will lead increasingly to research on the capacity of the state to regulate by redefining firms' social responsibilities and obligations in this new context, particularly those of organizations and groups of organizations that build internal labour markets.

28. A related issue is that we do not think that sociological research should distinguish, at the interorganizational level, between social niches and ecological niches. Sociologists such as Podolny et al., (1996) think that, in the second type of niche, companies depending on the same resources and endorsement mechanisms making coordination possible are enough to justify this distinction. In our view, the notion of a social niche encompasses this type of ecological niche and recognizes that more aggressive power relationships should often characterize interorganizational ties. Power relationships should not be distinguished in nature from simple 'endorsements'. Power that seems to be raw power is never very far from legitimization; indeed, what makes its use very often so scandalous is the fact that it is actually and silently legitimized by authorities (such as the state). Organizational ecology does not address issues of raw power in the ecological niche. Our approach using the idea of a social niche is an extended view of such entities, one that is able to include both endorsements and more brutal expressions of power. Organizational ecology and its emphasis on codependency on similar resources is not to be neglected. Without the power of a hierarchy between organizations, standardization of products, for example, is impossible and markets destroy themselves. Just as brainstorming at the intraorganizational level (example used above) would not stop, owing to status competition, without the intervention of hierarchical status, markets would not reach any standards. Hierarchy manages what is dysfunctional with the collegial social niche at the micro and meso levels. This transposition also works with regard to the use of identities (ethnic groups, 'classe patronale') underlying a social niche. Instead of asking what triggers the choice of an ecological over a social niche, we think that a social niche should account for market structuration, including for firms' codependency on similar resources usually attributed to ecological niches. The social niche does not require only contacts and relationships; sometimes it also requires power thanks to one's control of resources. Berkowitz's work (see above) can be seen as an example of the overlap of the two approaches. Actions influenced by the fact that one is a director of a company are not necessarily different from those deriving from the fact that one belongs to the same ethnic group. In our view, it is simpler to assume that there is only one kind of society in the market, even if two organizational forms (bureaucracy and collegiality) account for coordination among its actors.

29. White's (2001) approach to production markets actually reasons in terms of mechanisms, but it assumes their existence more than it actually models them, even from the perspective of individual entrepreneurs, not to mention the coordination of interdependent ones.

30. Stuart (1998) tries to show that strategic alliances have a positive effect on organizations' performance (growth and capacity to innovate) when the partners are themselves large and innovative.

31. Podolny and Stuart (1999) assume a technologically closed 'space', in which inventions at time $t 2$ are always derived from inventions from that same field at time $t 1$. Inventions in that industry, however, may come from firms in different industries (plastics, chemistry, biology) or from labs in the public sector (universities). Thus their account of industry evolution is limited to specific 'endogenous' processes and (probably) routine developments in the semiconductor industry.

32. This certainly improves on Hannan and Freeman's (1989) approach to competition in terms of numbers of producers in an industry. They claim that their definition of a niche is 'fundamental', as opposed to 'realized' (or based on market exchange relations which, they assert, have a 'transitory' character, that is, defined at one point in time and therefore not constraining on the actions of an organization). What makes this 'fundamental' character, however, is unclear: it may be the stability of the niche over time, or its lack of dependence on agency. More generally, it is possible to envisage that markets, when not regulated externally by the state, are structured in two different ways (that is, by two different types of niches): in an extended ecological way (organizational ecology plus power relationships in the construction of markets) and in a social way. But the extent to which it is useful to assume that there are two kinds of society in the market remains to be tested. The two often overlap to such 
an extent that the distinction may be useless. But, in special cases, they may not. For example, in private R\&D ventures, social niches may matter much more than extended ecological ones. A social niche requires heavy reliance on contacts, relationships and associated social mechanisms. The extended ecological niche simply requires a way to notifying the other parties of one's power over them via unchallengeable control of vital resources. The second is easier to enforce. Structures being multi-level, social niches might need a level of structuration that is superior in order to gain the level of influence that has the same effect as power in the extended ecological niche.

33. Such an approach was extended by the recent look at activities of endorsement (Podolny et al., 1996) and at coordination based on more aggressive power relationships, which was neglected in population ecology and recent attempts to combine it with structural sociology.

34. For example, control at the interorganizational level is being examined in a study of the balance between external (state-controlled) regulation and self-regulation of the business world in a study of commercial courts in France (Lazega and Mounier, forthcoming). In these courts, 'consular' (that is, not professional) and voluntary judges are appointed by the business community through the Chamber of Commerce. These judges come from various sectors of the economy, but mostly from banking and financial services, sectors that are particularly well positioned to exercise control at the interorganizational level when state agencies withdraw from part of their enforcement tasks. While performing such tasks, competitors do rely on this social discipline in order to cooperate, thus combining 'bureaucratic' and 'collegial' models of collective action.

\section{REFERENCES}

Aldrich, Howard E. and Peter M. Marsden (1988), 'Environments and Organizations', in Neil J.Smelser (ed.), Handbook of Sociology, Beverly Hills: Sage.

Anheier, Helmut and Wolfgang Seibel (1990), The Third Sector, Comparative Studies of Non-Profit Organization, Berlin: De Gruyter.

Baker, Wayne E. (1984), 'The social structure of a national securities market', American Journal of Sociology, 89, 775-811.

Baker, Wayne E. (1990), 'Market networks and corporate behavior', American Journal of Sociology, 96, 589-625.

Baker, Wayne E. (1992), 'The network organization in theory and practice', in Nitin Nohria and Robert G. Eccles (eds), Groups, Leadership and Men, Pittsburgh: Carnegie Press.

Baker, Wayne E. and Robert R. Faulkner (1993), 'The social organization of conspiracy, illegal networks in the heavy electrical equipment industry', American Sociological Review, 58, 837-60.

Baker, Wayne E., Robert R. Faulkner and Gene A. Fisher (1998), 'Hazards of the market, the continuity and dissolution of interorganizational market relationships', American Sociological Review, 63, 147-77.

Barley, S.R., J. Freeman and R.C. Hybels (1992), 'Strategic Alliances in Commercial Biotechnology', in N. Nohria and R. Eccles (eds), Networks and Organizations, Cambridge: Harvard Business School Press.

Baron, James N. and Michael T.Hannan (1994), 'The impact of economics on contemporary sociology', Journal of Economic Literature, 32, 1111-46.

Batenburg, Ronald, Werner Raub and Chris Snijders (1997), 'Contacts and contracts, temporal embeddedness and the contractual behavior of firms', Utrecht, Iscore Papers, no. 107. 
Bauer, Michel and Elie Cohen (1981), Qui gouverne les groupes industriels?, Paris: Seuil.

Bearman, Peter (1997), 'Generalized exchanges', American Journal of Sociology, 102, 1383-1415.

Berkowitz, Stephen D. (1982), An Introduction to Structural Analysis, Toronto: Butterworth.

Berkowitz, Stephen D. (1988), 'Markets and market-areas', in B. Wellman and S.D. Berkowitz (eds.), Social Structures, A Network Approach, Cambridge: Cambridge University Press.

Berkowitz, Stephen D. and William Fitzgerald (1995), 'Corporate control and enterprise structure in the Canadian economy, 1972-1987', Social Networks, 17, $11-127$.

Berkowitz, S.D., P.J. Carrington, Y, Kotowitz and L. Waverman (1979), 'Enterprise Groups', Social Networks, 1, 391-413.

Berle, Adolf A. and G.C.Means (1932), The Modern Corporation and Private Property, revised edn (1969), New York: Harcourt, Brace \& World.

Biencourt, Olivier, François Eymard-Duvernay and Olivier Favereau (1994a), 'Concurrence par la qualité et viabilité d'un marché, le cas du transport routier de marchandises', rapport au Commissariat Général du Plan, Laboratoire FORUM, Université Paris X et Centre d'Etude de l'Emploi, Novembre.

Biencourt, Olivier, François Eymard-Duvernay and Olivier Favereau (1994b), 'L'économie doit définir le marché à partir de l'entreprise, plutôt que l'inverse', Communication présentée au colloque de la Society for the Advancement of SocioEconomics, Paris, July.

Blau, J.R. and R.P. Alba (1982), 'Empowering Nets of Participation', Administrative Science Quarterly, 27, 363-79.

Blau, Peter M. (1964), Exchange and Power in Social Life, New York: John Wiley.

Blumer, H. (1969), Symbolic Interactionism, Englewood Cliffs, NJ: Prentice-Hall.

Boccara, Frédéric (1999a), 'Facts and myths in employment and SME growth: The role of enterprise groups (1984-1992)', Insee Working papers of the Direction des statistiques d'entreprise.

Boccara, Frédéric (1999b), 'Globalization, business groups and growth factors in France', Insee Working papers of the Direction des statistiques d'entreprise.

Boorman, Scott A. and Ronald L. Breiger (1976), 'Social Structure from Multiple Networks, I. Blockmodels of Roles and Positions', American Journal of Scoiology, $81,730-80$.

Boorman, Scott and Paul Levitt (1980), The Genetics of Altruism, New York: Academic Press.

Borgatti, Stephen and G. Martin Everett (1992), 'Notions of position in social networks analysis', Sociological Methodology, 22, 1-35.

Bosk, Charles (1979), Forgive and Remember, Chicago: University of Chicago Press.

Bourdieu, Pierre (1980), 'Le Capital social: Notes provisoires', Actes de la recherche en sciences sociales, 3: 2-3.

Bourdieu, Pierre (1990) [1984], The Logic of Practice, Stanford: Stanford University Press.

Bowles, Samuel (1995), 'Compte rendu sur le Handbook of Economic Sociology', Contemporary Sociology, 24, 304-7.

Bowles, Samuel and Herbert Gintis (1998), 'How communities govern, the structural basis of prosocial norms', in Avner Ben Ner and Louis Putterman (eds), Economics, Values and Organization, Cambridge: Cambridge University Press. 
Brass, Daniel J. (1984), 'Being in the right place: a structural analysis of individual influence in an organization', Administrative Science Quarterly, 29, 518-39.

Breiger, Ronald L. (1974), 'The duality of persons and groups', Social Forces, 53, 181-90.

Breiger , Ronald L. and J. Ennis (1997), 'Generalized exchange in social networks: statistics and structure', L'Année Sociologique, 47, 73-88.

Breiger, Ronald L., S. Boorman and P. Arabie (1975), 'An algorithm for clustering relational data with applications to social network analysis and comparison with multidimensional scaling', Journal of Mathematical Psychology, 12, 328-83.

Brint, Stephen (1992), 'Hidden meanings: cultural content and context in Harrison White's structural sociology', Sociology Theory, 10, 194-208.

Burt, Ronald S. (1983), Corporate Profits and Cooptation, New York: Academic Press.

Burt, Ronald S. (1988), 'The stability of American markets', American Journal of Sociology, 94, 356-95.

Burt, Ronald S. and Ronchi, D. (1990), 'Contested Control in a Large Manufacturing Plant', in Social Networks Through Time, J. Weesie et H. Flap, eds., Utrecht: ISOR.

Burt, Ronald S. (1992), Structural Holes, The Social Structure of Competition, Cambridge, MA: Harvard University Press.

Burt, Ronald S. (1993) 'Market integration', in S. Lindenberg and H. Schreuder (eds), Interdisciplinary Perspectives on Organization Studies, Oxford: Pergamon Press.

Burt, Ronald S. and I. Talmud (1993), 'Market niche', Social Networks, 8, 97-117

Capecchi, Vittorio (1987), 'Formation professionnelle et petite entreprise, le développement industriel à spécialisation flexible en Emilie-Romagne', FormationEmploi, no. 19, July-September, La Documentation française.

Carruthers, Bruce (1996), City of Capital, Politics and Markets in the English Financial Revolution, Princeton: Princeton University Press.

Carruthers, Bruce G. and Terence C.Halliday (1998), Rescuing Business, the Making of Corporate Bankruptcy Law in England and the United States, Oxford: Clarendon Press.

Chandler, Alfred D. (1962), Strategy and Structure, Chapters in the History of Industrial enterprise, Cambridge, MA: MIT Press.

Chandler, Alfred D. (1977), The Visible Hand. The Managerial Revolution in American Business, Cambridge, MA: Harvard University Press.

Chandler, Alfred D. (1990), Scale and Scope, The Dynamics of Industrial Capitalism, Cambridge, MA: Harvard University Press.

Chazel, François (1983), 'Pouvoir, structure et domination', Revue Française de Sociologie, 24, 369-93.

Cheit, Ross E. and Jacob E.Gersen (2000), 'When businesses sue each other, an empirical study of state court litigation', Law \& Social Inquiry, 25, 789-816.

Coase, Ronald H. ([1937] 1988), The Firm, the Market and the Law, Chicago: University of Chicago Press

Coleman, James S. (1990), Foundations of Social Theory, Cambridge, MA: Harvard University Press.

Comet, Catherine (2001), 'Les coopératives de petites entreprises du bâtiment', $\mathrm{PhD}$ thesis in preparation, University of Lille I.

Cook, Karen (ed.) (1987), Sociological Exchange Theory, London:Sage.

Cook, K.S. (1990), 'Linking Actors and Structures: An Exchange Network Perspective', in Calhoun, Meyer and Scott (eds),

Crozier, Michel (1963), Le phénomène bureaucratique, Paris:Seuil.

Crozier, Michel and E. Friedberg (1977), L'acteur et le système, Paris: Seuil. 
Davis, G.F. (1991), 'Agents without principle? The spread of the poison pill through the intercorporate network', Administrative Science Quarterly, 36, 583-613.

Davis, Gerald F. et Powell, Walter W. (1992), 'Organization-Environment Relations', in M.D. Dunnette et L.M. Hough (eds.), Handbook of industrial and organizational psychology, second edition, volume III, Palo Alto: Consulting Psychology Press.

Degenne, Alain and Michel Forsé (1994), Les réseaux sociaux, Paris: Colin.

Dezalay, Yves and Garth, Bryant (1996). Dealing in virtue: International commercial arbitration and the construction of a transnational legal order, Chicago: Univeristy of Chicago Press.

DiMaggio, Paul (1986), 'Structural analysis of organizational fields', in B. Staw and L.L. Cummings (eds), Research in Organizational Behavior, Greenwich, CT: JAI Press, vol. 8, pp. 335-70.

DiMaggio, Paul (1991), 'The micro/macro dilemma in organizational research: implications of role-systems theory', in J. Huber (ed.), Macro-Micro Relationships, Newbury Park, CA: Sage.

DiMaggio, Paul (1992), 'Nadel's paradox revisited: relational and cultural aspects of organizational culture', in Nitin Nohria and Robert G. Eccles (eds), Groups, Leadership and Men, Pittsburgh: Carnegie Press.

Dunworth, Terence and Joel Rogers (1996), 'Corporations in court, big business litigation in U.S. Federal Courts, 1971-1991', Law \& Social Inquiry, 21, 497-592.

Dyer, J.H. and H. Singh (1998), 'The relational view, cooperative strategy and sources of interorganizational competitive advantage', Academy of Management Review, $23,660-79$.

Eccles, Robert (1985), The Transfer Pricing Problem, Lexington, MA: Lexington Books.

Eccles, Robert G. and Dwight B. Crane (1988), Doing Deals: Investment Banks at Work, Boston: Harvard Business School Press.

Ekeh, Peter (1976), Social Exchange Theory: The Two Traditions, Cambridge, MA: Harvard University Press.

Encaoua, David and Alexis Jacquemin (1982), 'Organizational efficiency and monopoly power. The case of French industrial groups', European Economic Review, 19, 25-51.

Eymard-Duvernay, François and Favereau, Olivier (1990), 'Marchés internes, modèles d'entreprises et conventions de qualité, matériaux pour une formalisation non standard du marché des biens', Communication aux 7èmes journées de MicroEconomie Appliquée, Université du Québec à Montréal, May.

Farkas, George, Kevin Lang and Paula England (1994), 'Economic sociology and social economics, where are we now?', in George Farkas and Paula England (eds), Industries, Firms and Jobs, Sociological and Economic Approaches, New York: De Gruyter .

Favereau, Olivier (1989), 'Marchés internes, marchés externes', Revue économique, 40(2), 273-328.

Favereau, Olivier (1998), 'Décisions, situations, institutions', in A.Vinokur (ed.), Décisions économiques, Paris: Economica.

Favereau, Olivier (1999), 'L'Economie des conventions et le constructivisme en économie', in G.R.A.S.C.E. (ed.), Entre systémique et complexité, chemin faisant. Mélanges en l'honneur de J.L.Lemoigne, Paris: Presses Universitaires de France.

Ferrand, Alexis (1997), 'La structure des systèmes de relations', L'Année Sociologique, $47,37-54$.

Festinger, Leon (1954), 'A theory of social comparison processes', Human Relations, $7,117-40$ 
Flap, Hendrik D., Bert Bulder and B. Völker (1998), 'Intra-organizational networks and performance: a review', Computational and Mathematical Organization Theory, 4, 1-39.

Fligstein, Neil (1990), The Transformation of Corporate Control, Cambridge, MA: Harvard University Press.

Fligstein, Neil (forthcoming), Ruling Markets, An Economic Sociology of Capitalist Societies, Princeton: Princeton University Press

Fligstein, Neil and Iona Mara-Drita (1996), 'How to make a market', American Journal of Sociology, 102, 1-33

Freidson, Eliott (1975), Doctoring Together: A Study of Professional Social Control, New York: Elsevier.

Freidson, Eliott (1986), Professional Powers, Chicago: University of Chicago Press.

Friedberg, Erhard (1993), Le pouvoir et la règle, Paris: Seuil.

Gabbay, Shaul M. (1997), Social Capital in the Creation of Financial Capital: The Case of Network Marketing, Champaign, IL: Stipes Publishing.

Galaskiewicz, J. (1979), 'The structure of community interorganizational networks', Social Forces, 57, 1346-64.

Galaskiewicz, J. (1989), 'Interorganizational networks mobilizing action at the metropolitan level', in Perucci R. and Potter H.R. (eds), Networks of Power, New York: Aldine de Gayter.

Galaskiewicz, J. and P.V. Marsden (1978), 'Interorganizational Resource Networks: Formal Patterns of Overlap', Social Science Research, 7, 89-107.

Gargiulo, Martin (1993), 'Two-step leverage: managing constraint in organizational politics', Administrative Science Quarterly, 38, 1-19.

Ghoshal, S. and J. Nahapiet (1998), 'Social capital, intellectual capital and the organizational advantage', Academy of Management Review, 23, 242-66.

Gouldner, Alvin W. (1954), Patterns of Industrial Bureaucracy, New York: Free Press.

Gouldner, Alvin W. (1960), 'The norm of reciprocity', American Sociological Review, $25,161-78$.

Granovetter, Mark (1985), 'Economic action and social structure, the problem of embeddedness', American Sociological Review, 91, 481-510.

Granovetter, Mark (1992), 'Problems of explanation in economic sociology', in N. Nohria and R. Eccles (eds), Networks and Organizations, Cambridge, MA: Harvard, Business School Press.

Granovetter, M. (1994), 'Business Groups', in Neil Smelser and Richard Swedberg (eds), Handbook of Economic Sociology, Princeton, NJ: Russell Sage Foundation.

Gulati, Ranjay (1995), 'Social structure and alliance formation patterns: A longitudinal analysis', Administrative Science Quarterly, 40, 619-50.

Han, Shin-Kap and Ronald L. Breiger (1999), 'Dimensions of Corporate Social Capital: Toward Models and Measures', in Roger Leenders and Shaul Gabbay (eds), Corporate Social Capital and Liability, Boston: Kluwer.

Hannan, Michael T. and John Freeman (1989), Organizational Ecology, Cambridge, MA: Harvard University Press.

Harrison, Bennett (1994), Lean and Mean, The Changing Landscape of Corporate Power in the Age of Flexibility, New York: Basic Books.

Hawkins, Keith O. (1984), Environment and Enforcement, Oxford: Oxford University Press.

Heckathorn, Douglas (1989), 'Collective action and the second-order free-rider problem', Rationality and Society, 1, 78-100. 
Hedström, Peter and R. Swedberg (1998), Social Mechanisms, Cambridge: Cambridge University Press.

Hirsch, Paul M. (1997), 'Sociology with social structure. Neoinstitutional theory meets brave new world', American Journal of Sociology, 102, 1702-23.

Hirsch, Paul M., Stuart Michaels and Ray Friedman (1987), 'Dirty hands versus clean models. Is sociology in danger of being seduced by economics?', Theory and Society, 16, 317-36.

Ibarra, H. (1992), 'Homophily and Differential Returns: Sex Differences in Network Structure and Access in an Advertising Firm', Administrative Science Quarterly, 37, 422-47.

Kalleberg, Arne L. (1995), 'Sociology and economics, crossing the boundaries', Social Forces, 73, 1207-18.

Kapferer, B.C. (1969), 'Norms and the manipulation of relationships in a work context', in J.C. Mitchell (ed.), Social Networks in Urban Situations, Manchester: Manchester University Press, pp. 181-245.

Kapferer, B.C. (1972), Strategy and Transaction in an African Factory, Manchester: Manchester University Press.

Karpik, Lucien (1989), 'L'économie de la qualité', Revue Française de Sociologie, 30, 187-210.

Kellerhals, Jean, Marianne Modak and Massimo Sardi, with the collaboration of Noëlle Languin and Renaud Lieberherr (1995), 'Justice, sens de la responsabilité et relations sociales', L'Année Sociologique, 45, 317-49.

Knoke, David (1987), Political Networks, Cambridge: Cambridge University Press.

Knoke, D. and J. Wood (1981), Organized for Action: Commitment in Voluntary Associations, New Brunswick, NJ: Rutgers University Press.

Kogut, Bruce and Zander, Udo B. (1996), 'What firms do: Coordination, identity and learning', Organization Studies, 7, 502-18.

Krackhardt, David (1987), 'Cognitive Social Structures', Social Networks, 9, 109-34.

Krackhardt, David (1990), 'Assessing the political landscape: structure, cognition and power in organizations', Administrative Science Quarterly, 35, 342-69.

Krackhardt, David (1992), 'The Strength of Strong Ties: The Importance of Philos in Organizations', in Nohria, N. and Eccles, R. (eds.) (1992), Networks and Organizations, Cambridge, Harvard Business School Press.

Krackhardt, David and J.R. Hanson (1993), 'Informal networks: the company behind the chart', Harvard Business Review, July-August, 104-11.

Kuty, Olgierd (1998), La négociation des valeurs : introduction à la sociologie, Brussels: De Boeck \& Larcier.

Laumann, Edward O. and Peter V. Marsden (1982), 'Microstructural analysis in interorganizational systems', Social Networks, 4, 329-48.

Laumann, Edward O. and David Knoke (1987), The Organizational State, Madison: University of Wisconsin Press.

Laville, Jean-Louis (1994), 'Economie et société, pour un retour à une problématique fondatrice de la sociologie', Sociologie du Travail, 36, 239-49.

Lazega, Emmanuel (1990), 'Internal Politics and the Interactive Elaboration of Information in Workgroups: An Exploratory Study', Human Relations, 43, 87-101.

Lazega, Emmanuel (1992a), The Micropolitics of Knowledge, Communication and Indirect Control in Workgroups, New York: Aldine-de Gruyter.

Lazega, Emmanuel (1992b), 'Analyse de réseaux d'une organisation collégiale, les avocats d'affaires', Revue Française de Sociologie, 33, 559-89.

Lazega, Emmanuel and Stéphane Vari, (1992), 'Acteurs, cibles et leviers. Analyse 
factorielle des relations de contrôle indirect dans une firme américaine d'avocats d'affaires', Bulletin de Méthodologie Sociologique, 37, 41-51.

Lazega, Emmanuel (1993), 'Bureaucratie et collégialité dans les firmes américaines d'avocats d'affaires', Droit et Société, 23/24, 15-40.

Lazega, Emmanuel (1994a), 'Analyse de réseaux et sociologie des organisations', Revue Française de Sociologie, 35, 293-320.

Lazega, Emmanuel (1994b), 'Les conflits d'intérêts dans les cabinets américains d'avocats d'affaires, concurrence et auto-régulation', Sociologie du Travail, 35, 315-36.

Lazega, Emmanuel (1995), 'Concurrence, coopération et flux de conseil dans un cabinet américain d'avocats d'affaires, Les échanges d'idées entre collègues', Revue Suisse de Sociologie, 1, 61-84.

Lazega, Emmanuel and Marie-Odile Lebeaux (1995), 'Capital social et contrainte latérale', Revue Française de Sociologie, 36, 759-77.

Lazega, Emmanuel (1996), 'Arrangements contractuels et structures relationnelles', Revue Française de Sociologie, 37, 439-56.

Lazega, Emmanuel (1997), 'Network analysis and qualitative research. A method of contextualization', in Gale Miller and Robert Dingwall (eds), Context and Method in Qualitative Research, London: Sage.

Lazega, Emmanuel and Marijtje van Duijn (1997), 'Position in formal structure, personal characteristics and choices of advisors in a law firm. A logistic regression model for dyadic network data', Social Networks, 19, 375-97.

Lazega, Emmanuel (1999a), 'Le phénomène collégial, une théorie structurale de l'action collective entre pairs', Revue Française de Sociologie, 4 (40) 639-70.

Lazega, Emmanuel (1999b), 'Generalized exchange and economic performance', in Roger Leenders and Shaul Gabbay (eds), Corporate Social Capital and Liabilities, Boston: Kluwer.

Lazega, Emmanuel and Philippa Pattison (1999), 'Multiplexity, generalized exchange and cooperation in organizations', Social Networks, 21, 67-90.

Lazega Emmanuel and Lise Mounier (1999), 'Analyse secondaire de l'enquête. Liaisons industrielles d'un point de vue sociologique: une expérience inaboutie', Rapport au service des Statistiques industrielles du Ministère de l'Industrie.

Lazega, Emmanuel (2000a), 'Teaming Up and Out? Cooperation and solidarity in a collegial organization', European Sociological Review, 16, 245-66.

Lazega, Emmanuel (2000b), 'Enforcing rules among peers, A lateral control regime', Organisation Studies, 21, 193-214.

Lazega, Emmanuel (2000c), 'Les entrepreneurs interdépendants et les mécanismes sociaux de leur coopération', Communication à la Journée d'étude Le réseau, acteur et objet de régulation, Maison des Sciences de l'Homme, Nantes, 17 November.

Lazega, Emmanuel (2000d), 'Le troc comme mécanisme social, une approche structurale', Présentation à la journée d'étude De la sociologie économique à la sociologie de l'action économique, Ecole Normale Supérieure-Cachan, 10 November.

Lazega, Emmanuel (2000e), 'Structure and Culture in the Constitutional Process, Multi-status Oligarchs and the Negotiation of Precarious Values', paper presented at the American Sociological Association Annual Meeting, Social Networks section, Washington DC, August.

Lazega, Emmanuel (2000f), 'Networks, distributed knowledge and economic performance', conference on 'The Economics and Socio-Economics of Services, International Perspectives', Lille-Roubaix, 22-3 June.

Lazega, Emmanuel and David Krackhardt (2000), 'Spreading and shifting costs of 
lateral control in a law partnership, A structural analysis at the individual level', Quality and Quantity, 34, 153-75.

Lazega, Emmanuel (2001a), The Collegial Phenomenon, The Social Mechanisms of Cooperation among Peers in a Corporate Law Firm, Oxford: Oxford University Press.

Lazega, Emmanuel (2001b), 'Who Guards the Guardians? A Lateral Control Mechanism as a Form of Corporate Social Capital', in Roger Leenders and Shaul Gabbay (eds), Research in the Sociology of Organizations, vol. 8, 263-91.

Lazega, Emmanuel and Philippa Pattison (2001), 'Social mechanisms as a form of corporate social capital, status auctions among peers', in Nan Lin, Karen Cook and Ronald Burt (eds), Social Capital, Theory and Research, New York: Aldine-de Gruyter.

Lazega, Emmanuel and Mounier, Lise (forthcoming), 'Interlocking judges: commercial courts and the governance of markets in France', Research in the Sociology of Organizations.

Leifer, Eric M. and Harrison C. White (1988), 'A structural approach to markets', in Mark S. Mizruchi and Michael Schwartz (eds), Intercorporate relations: the structural analysis of business, New York: Cambridge University Press.

Lemieux, V. (1979), Les cheminements de l'influence, Québec: Presses de l'Université Laval.

Lemieux, V. (1982), Réseaux et appareil, Québec: Edisem, Paris: Maloine.

Levi-Strauss, C. (1949), Les formes élémentaires de la parenté, Paris:Plon.

Levine, Sol and Paul E. White (1961), 'Exchange as a conceptual framework for the study of interorganizational relationships', Administrative Science Quarterly, 5, 583-601.

Lin, Nan (1982), 'Social resources and instrumental action', in Peter V. Marsden and Nan Lin (eds), Social Structure and Network Analysis, London: Sage.

Lin, Nan (2001), Social Capital, Cambridge: Cambridge University Press.

Lindenberg, Siegwart (1991), 'Homo socio-oeconomicus, the emergence of a general model of man in the social sciences', Journal of Institutional and Theoretical Economics, 146, 727-48.

Lindenberg, Siegwart (1992), 'An extended theory of institutions and contractual discipline', Journal of Institutional and Theoretical Economics, 148, 125-54.

Lindenberg, Siegwart (1996), 'Multiple-tie networks, structural advantage, and pathdependency, another look at hybrid forms of governance', Journal of Institutional and Theoretical Economics, 152, 188-96.

Macaulay, Stewart (1963), 'Non-contractual relations in business, a preliminary study', American Sociological Review, 28 , 55-67.

McCall, G.J. and J.L. Simmons (1966), Identities and interactions, New York: Collier-Macmillan.

Mintz, Beth and Schwartz, Michael (1985), The Power Structure of American Business, Chicago: University of Chicago Press.

Mizruchi, Mark (1982), The American Corporate Network: 1904-974, Beverly Hills: Sage.

Mizruchi, Mark (1989), 'Similarity of political behavior among large American corporations', American Journal of Sociology, 95, 401-24.

Mizruchi, Mark (1992), The Structure of Corporate Political Action: Interfirm Relations and their Consequences, Cambridge, MA: Harvard University Press.

Mokken, R. and F. Stokman (1978), 'Corporate governmental networks in the Netherlands', Social Networks, 1, 333-58. 
Morin, François and Claude Dupuy (1993), Le cour financier européen, Paris: Economica.

Nadel, Sigfried F. (1957), The Theory of Social Structure, London: Cohen \& West.

Nee, Victor (1998), 'Norms and networks in economic and organizational performance', American Economic Review, 88, 85-9.

Nohria, Nitin and Robert Eccles (eds) (1992), Networks and Organizations, Cambridge, MA: Harvard Business School Press.

North, Douglass (1993), 'Institutions and Credible Commitments', Journal of Institutional and Theoretical Economics, 149,11-23.

Oliver, Pamela (1980), 'Rewards and punishments as selective incentives for collective action: theoretical investigations', American Journal of Sociology, 85, 356-75.

Olson, Mancur (1965), The Logic of Collective Action, Cambridge, MA: Harvard University Press.

Padgett, John F. et Ansell, C.K. (1989), 'Robust action and the rise of the Medici, 1400-1434', American Journal of Sociology, 98, 1259-1319.

Padgett, John F. (2000), 'Organizational genesis, identity and control, the transformation of banking in Renaissance Florence', in A. Casella and J. Rauch (eds), Markets and Networks, New York: Russell Sage.

Pappi, F.U. et König, T. (1995), 'Les Organisations centrales dans les réseaux du domaine politique: Une comparaison Allemagne-Etats-Unis dans le champ de la politique du travail', Ravue française de sociologie, 725-42.

Perrow, C. (1992), 'Small-firm networks', in N. Nohria and R. Eccles (eds), Networks and Organizations, Cambridge, MA: Harvard Business School Press.

Perrow, Charles (1991), 'A society of organizations', Theory and Society, 20, 725-62.

Perucci, R. and Potter, H.R (eds.) (1989), Networks of Power, New York, Aldine-de Gruyter.

Piore, Michael and Charles Sabel (1984), The Second Industrial Divide, New York: Basic Books.

Pizarro, Narciso (1999), ‘Appartenances, places et réseaux de places, la reproduction des processus sociaux et la génération d'un espace homogène pour la définition des structures sociales', Sociologie et Sociétés, 31, 143-61.

Podolny, Joel M. (1993), 'A status-based model of market competition', American Journal of Sociology, 98, 829-72.

Podolny, Joel M. (1994), 'Market uncertainty and the social character of economic exchange', Administrative Science Quarterly, 39, 458-83.

Podolny, Joel M. and Toby E. Stuart (1995), 'A role-based ecology of technological change', American Journal of Sociology, 100, 124-1260.

Podolny, Joel M., Toby E. Stuart and Michael T. Hannan (1996), 'Networks, knowledge, and niches, competition in the worldwide semiconductor industry, 1984-1991', American Journal of Sociology, 102, 659-89.

Podolny, Joel and Stuart, Toby (1999), 'Positional causes and correlates od strategic alliances in the semiconductor industry', Research in the Sociology of Organizations, 16, 161-82.

Powell, Walter W. (1990), 'Neither market nor hierarchy, network forms of organization', in L.L. Cummings and B. Shaw (eds), Research in Organizational Behavior, vol. 12, Greenwich, CT: JAI Press.

Powell, W.W., K.W. Koput and L. Smith-Doerr (1996), 'Interorganizational collaboration and the locus of innovation: networks of learning in biotechnology', Administrative Science Quarterly, 41, 116-45.

Presthus, R. (1962), The Organizational Society, New York: Knopf. 
Raub, Werner and Jeroen Weesie (1990), 'Reputation and efficiency in social interactions: an example of network effects', American Journal of Sociology, 96, 626-54.

Raub, Werner and Jeroen Weesie (1993), 'Symbiotic arrangements, a sociological perspective', Journal of Institutional and Theoretical Economics, 149, 716-24.

Raub, Werner and Jeroen Weesie (1996), 'The management of matches, decentralized mechanisms for cooperative relations with applications to organizations and households', Utrecht, Iscore Papers, no. 62.

Raub, Werner and Jeroen Weesie (eds) (2000), The Management of Durable Relations, Theoretical and Empirical Models for Households and Organizations, Amsterdam: Thela Publishers.

Reiss, Albert J. Jr. (1984), 'Selecting strategies of social control over organizational life', in Keith O. Hawkins and James M. Thomas (eds), Enforcing Regulation, Boston: Kluwer-Nijhof.

Reitz, K.P. (1988), 'Social Groups in a Monastery', Social Networks, 10 (4), 343-57.

Reynaud, Jean-Daniel (1988), 'Les régulations dans les organisations, régulation de contrôle et régulation autonome', Revue Française de Sociologie, 29, 5-18.

Reynaud, Jean-Daniel (1989), Les règles du jeu, Paris: Armand Colin.

Rogers, E.M. and R. Agarwala-Rogers (1976), Communication in Organizations, New York: Free Press.

Rooks, Gerrit, Werner Raub, Robert Selten and Frits Tazelaar (2000), 'How inter-firm cooperation depends on social embeddedness. A vignette study', Acta Sociologica, $43,123-37$.

Sabel, Charles (1989), 'Flexible specialization and the re-emergence of regional economics', in P. Hirst and J. Zeitlin (eds), Reversing Industrial Decline?, London: Berg.

Sabel, Charles (1993), 'Constitutional ordering in historical context', in Fritz W. Scharpf (ed.), Games in Hierarchies and Networks, Frankfurt am Main: Campus Verlag.

Sainsaulieu, Renaud (1977), L'Identité au travail, Paris, Presses de la Foundation Nationale des Sciences Politiques.

Sainsaulieu, Renaud (1987), Sociologie de l'organisation et de l'entreprise, Paris: Presses de la Fondation Nationale des Sciences Politiques.

Salancik, G.R. and J. Pfeffer (1977), 'Who gets power - and how they hold onto it: a strategic contingency model of power', Organizational Dynamics, 5, 3-21.

Sampson, S. (1969), 'Crisis in a Cloister', PhD dissertation, Cornell University.

Saxenian, Anna Lee (1994), Regional Advantage, Culture and Competition in Rt. 128 and Silicon Valley, Cambridge, MA: Harvard University Press.

Schwartz, M. and M. Mizruchi (eds) (1988), The Structural Analysis of Business, Cambridge: Cambridge University Press.

Scott, W.R. (1975), 'Organizational structure', in A. Inkeles, J. Coleman and N.Smelser (eds), Annual Review of Sociology, Palo Alto, CA: Annual Reviews Inc.

Shrader, C.B., J.R. Lincoln and A.N. Hoffman (1989), 'The network structures of organizations: effects of task contingencies and distributional form', Human Relations, 42, 43-66.

Selznick, Philip (1957), Leadership in Administration, Evanston, IL: Row, Peterson \& Co.

Shapiro, Susan P. (1984), Wayward Capitalists, Target of the Securities and Exchange Commission, New Haven: Yale University Press.

Simpson, Richard L. (1971), 'Imperative Control, Associationalism, and the Moral Order', in Turk, Herman and Simpson, Richard L. (eds.), Institutions and Social Exchange, New York: Bobbs-Merrill. 
Smelser, Neil and Richard Swedberg (eds) (1994), Handbook of Economic Sociology, Princeton, NJ: Princeton University Press, and New York: Russell Sage Foundation. Stevenson, William B. (1990), 'Formal structure and networks of interaction within organizations', Social Science Research, 19, 113-31.

Stinchcombe, A.L. (1989), 'An outsider's view of network analyses of power', in Perucci, R. and Potter, H.R. (eds), Networks of Power, New York: Aldine-de Gauyter.

Stinchcombe, Arthur L (1991), 'The conditions of fruitfulness in theorizing about mechanisms in the social sciences', Philosophy of the Social Sciences, 21, 367-88.

Stofer, Rafaël (2001), 'Réseaux de relations sociales et professionnelles au sein de l'élite des chercheurs sur le cancer en France', Phd thesis in preparation, University of Lille I.

Stokman, F.N., M.A.L.M. van Assen, J. van der Knoop and R.C.H. van Oosten (2000), 'Strategic Decision Making', Advances in Group Processes (17), 131-53.

Stokman, Frans N., Rolf Ziegler and John Scott (eds) (1985), Networks of Corporate Power, Cambridge: Polity Press.

Strachan, Harry (1976), Family and Other Business Groups in Economic Development, New York: Praeger.

Stryker, Sheldon (1980), Symbolic interactionism: a social structural version, London: Benjamin/Cummings.

Stryker, Sheldon and Statham, A. (1985), 'Symbolic Interaction and Role Theory', in Gardner Lindzey and Elliot Aronson (eds), Handbook of Sociol Psychology, 3rd ed;. vol. 1, New York: andom House.

Stuart, Toby E. (1998), 'Network positions and propensities to collaborate, an investigation of strategic alliance formation in a high-technology industry', Administrative Science Quarterly, 43, 668-98.

Stuart, Toby E. and Joel M.Podolny (1999), 'Positional causes and correlates of strategic alliances in the semiconductor industry', in Research in the Sociology of Organizations, 16, 161-82.

Swedberg, Richard (ed.) (1990), Economics and Sociology, Princeton, NJ: Princeton University Press.

Swedberg, Richard (ed.) (1992), Explorations in Economic Sociology, New York: Sage.

Swedberg, Richard (1993), 'Economics and custom', Journal of Institutional and Theoretical Economics, 149, 204-9.

Swedberg, Richard (1994), 'Markets as social structures', in Neil Smelser and Richard Swedberg (eds), Handbook of Economic Sociology, Princeton, NJ: Princeton University Press, and New York, Russell Sage Foundation.

Talmud, Ilan and Gustavo S. Mesch (1997), 'Market Embeddedness and Corporate Instability, the Ecology of Inter-Industrial Networks', Social Science Research, $1-23$.

Thurman, B. (1980), 'In the office: networks and coalitions', Social Networks, 2, 47-63.

Useem, Michael (1984), The Inner Circle: Large Corporations and the Rise of Business

Political Activity in the US and UK, Oxford: Oxford University Press.

Uzzi, Brian (1996), 'The sources and consequences of embeddedness for the economic performance of organizations, The network effect', American Sociological Review, 61, 674-98.

Uzzi, Brian (1997), 'Social structure and competition in interfirm networks. The paradox of embeddedness', Administrative Science Quarterly, 42, 35-67. 
Uzzi, Brian (1999), 'Embeddedness in the making of financial capital: how social relations and network benefit firms seeking capital', American Sociological Review, 64, 481-505.

Uzzi, Brian and James J.Gillespie (1999), 'Interfirm ties and the organization of firm's capital structure in the middle financial market', in David Knoke and Steven Andrews (eds), Research in the Sociology of Organizations, Greenwich, CT: JAI Press.

Varanda, Marta (2001), 'Réseaux et mobilisation de PME commerciales dans le cadre d'un réaménagement urbain', $\mathrm{PhD}$ thesis in preparation, University of Lille I.

Vaughan, Diane (1983), Controlling Unlawful Organizational Behavior, Chicago: University of Chicago Press.

Vaughan, Diane (1999), 'The dark side of organizations, mistake, misconduct and disaster', Annual Review of Sociology, 25, 271-305.

Wasserman, Stanley and Katherine Faust (1994), Social Network Analysis, Theory and Applications, Cambridge: Cambridge University Press.

Wattebled, Olivier (2001), 'Bureaucratie et collégialité dans le Diocèse de Versailles', $\mathrm{PhD}$ Thesis in preparation, University of Lille I.

Weber, Max (1978), Economy and Society, Berkeley: University of California Press.

Wellman, Barry and Stephen D. Berkowitz (eds) (1988), Social Structures, A Network Approach, Cambridge: Cambridge University Press.

White, H.C. (1970), Chains of Opportunity: System Models of Mobility in Organizations, Cambridge, MA: Harvard University Press.

White, Harrison C., Boorman, Scott C. and Breiger, Ronald L. (1976), 'Social Structure From Multiple Networks I. Blockmodels of Roles and Positions', American Journal of Sociology, 81, 730-80.

White, Harrison C. (1981a), 'Production markets as induced role structures', in S.L. Leinhardt (ed.), Sociological Methodology, San Francisco: Jossey-Bass, pp. 1-57.

White, Harrison (1981b), 'Where do markets come from?', American Journal of Sociology, 87, 517-47.

White, Harrison (1988), 'Varieties of markets', in B. Wellman and S.D. Berkowitz (eds), Social Structures, A Network Approach, Cambridge: Cambridge University Press.

White, Harrison (2000), 'Markets and firms, Notes on the future of economic sociology', paper presented at the Second Annual Conference on Economic Sociology, University of Pennsylvania.

White, Harrison, with the collaboration of Matthew S.Bothner (2001), Markets from Networks, Princeton, NJ: Princeton University Press.

Williamson, Oliver (1975), Markets and Hierarchies, Analysis of Antitrust Implications, New York: Free Press.

Williamson, Oliver (1981), 'The economics of organization, the transaction cost approach', American Journal of Sociology, 87, 548-611.

Williamson, Oliver (1985), The Economic Institutions of Capitalism, New York:Free Press.

Williamson, Oliver E. (1996), The Mechanisms of Governance, New York: Oxford University Press.

Yamagishi, Toshio (1986), 'The Provision of a Sanctioning System as a Public Good', Journal of Personality and Social Psychology, 51, 110-16. 